\title{
Naar een arbeidsmarktmonitor voor de groene sector
}

Citation for published version (APA):

Bijlsma, I., Dijksman, S., Fouarge, D., Gerards, R., \& Steens, S. (2021). Naar een arbeidsmarktmonitor voor de groene sector. ROA. ROA Reports No. 001 https://doi.org/10.26481/umarep.2021001

Document status and date:

Published: 31/03/2021

DOI:

10.26481/umarep.2021001

Document Version:

Publisher's PDF, also known as Version of record

\section{Please check the document version of this publication:}

- A submitted manuscript is the version of the article upon submission and before peer-review. There can be important differences between the submitted version and the official published version of record.

People interested in the research are advised to contact the author for the final version of the publication, or visit the DOI to the publisher's website.

- The final author version and the galley proof are versions of the publication after peer review.

- The final published version features the final layout of the paper including the volume, issue and page numbers.

Link to publication

\footnotetext{
General rights rights.

- You may freely distribute the URL identifying the publication in the public portal. please follow below link for the End User Agreement:

www.umlib.nl/taverne-license

Take down policy

If you believe that this document breaches copyright please contact us at:

repository@maastrichtuniversity.nl

providing details and we will investigate your claim.
}

Copyright and moral rights for the publications made accessible in the public portal are retained by the authors and/or other copyright owners and it is a condition of accessing publications that users recognise and abide by the legal requirements associated with these

- Users may download and print one copy of any publication from the public portal for the purpose of private study or research.

- You may not further distribute the material or use it for any profit-making activity or commercial gain

If the publication is distributed under the terms of Article $25 \mathrm{fa}$ of the Dutch Copyright Act, indicated by the "Taverne" license above, 
Maastricht University

\section{Naar een arbeidsmarktmonitor voor de groene sector}

Ineke Bijlsma

Sander Dijksman

Didier Fouarge

Ruud Gerards

Sanne Steens

\section{ROA Rapport}

ROA-R-2021/1

Researchcentrum voor Onderwijs en Arbeidsmarkt | ROA Research Centre for Education and the Labour Market / ROA 


\title{
Colofon
}

(c) Researchcentrum voor Onderwijs en Arbeidsmarkt (ROA). Niets uit deze uitgave mag op enige manier worden verveelvoudigd zonder voorafgaande schriftelijke toestemming van de directeur van het ROA.

\author{
Researchcentrum voor Onderwijs en Arbeidsmarkt \\ Postbus 616 \\ 6200 MD Maastricht \\ $\mathrm{T}+31433883647$ \\ $\mathrm{F}+31433884914$ \\ secretary-roa-sbe@maastrichtuniversity.nl \\ www.roa.nl \\ School of Business and Economics \\ Maastricht University \\ Vormgeving \\ ROA secretariaat, Maastricht
}

ISBN: 978-90-5321-597-5

ISSN: 2666-8858

april 2021 


\section{Inhoud}

Voorwoord v v v v v v

Resumé vii

1 Inleiding 1

2 Analyse van bestaande prognose informatie voor de groene sector 3

2.1 Colland Arbeidsmarkt 3

2.2 Stigas 4

2.3 UWV

$2.4 \mathrm{ROA} \quad 6$

$\begin{array}{lll}2.5 \mathrm{SBB} & 7\end{array}$

2.6 Groenpact 8

2.7 Overeenkomsten en blinde vlekken bestaand arbeidsmarktonderzoek groene sector

3 Verdiepende analyses van de overgang van onderwijs naar arbeidsmarkt in de groene sector

3.1 Ontwikkeling classificatie groene sector i.s.m. Groenpact 11

3.2 Ontwikkeling in het aantal deelnemers in groen onderwijs 12

$\begin{array}{ll}\text { 3.3 Ontwikkeling in aantal gediplomeerden van groen onderwijs } & 14\end{array}$

3.4 Het rendement van groene opleidingen in termen van doorstroom- en arbeidsmarktuitkomsten

3.4.1 Doorstroom naar een andere opleiding na behalen van een 'groen diploma' 16

3.4.2 Ontwikkeling op de arbeidsmarkt na diplomering 19

$\begin{array}{lll}3.5 & \text { Kort en krachtig hoofdstuk } 3 & 31\end{array}$

4 Analyses van de taken en ontwikkelinspanningen van werkenden in groene beroepen

4.1 Kort en krachtig hoofdstuk 4

5 Verdiepende analyse van de beroepen- en sectorale mobiliteit in de groene sector

5.1 In hoeverre hebben groene beroepen een sterke binding met groene sectoren?

5.2 Mobiliteit van en naar de groene sector 
5.3 Kort en krachtig hoofdstuk 5

6 Conclusie en doorkijk 43

$\begin{array}{lr}\text { Literatuur } & 47\end{array}$

$\begin{array}{lr}\text { Appendix } & 49\end{array}$ 


\section{Voorwoord}

De uitdagingen die de groene transitie met zich meebrengt zijn groot. De groene sector heeft een belangrijke rol in het oplossen van opgaven rondom klimaat, voedselsystemen, biodiversiteit en de leefomgeving. Als onderdeel van Groenpact zetten partijen in het groene domein zich samen in voor onderwijsvernieuwing en praktijkinnovatie voor een betekenisvolle bijdrage aan deze maatschappelijke uitdagingen en voor een duurzame concurrentiekracht van de groene sector. Om dergelijke uitdagingen aan te kunnen is een goede aansluiting tussen de gevraagde vaardigheden op de arbeidsmarkt en de aangeboden vaardigheden vanuit het onderwijs van groot belang. Dit rapport bevat de bevindingen van sectorspecifiek onderzoek op basis van bestaande data, naar de aansluiting tussen onderwijs en arbeidsmarkt in de groene sector. Dit onderzoek biedt daarmee ook een inzicht in wat er met de bestaande data infrastructuur kan worden onderzocht als we de focus leggen op het bestuderen van één specifieke sector.

Het onderzoek is uitgevoerd als onderdeel van het Project Onderwijs-Arbeidsmarkt (POA) waaraan het Ministerie van Landbouw, Natuur en Voedselkwaliteit (LNV) financieel bijdraagt via NRO (Dossiernummer 405-17-900).' Dit rapport is tot stand gekomen in nauwe samenwerking en afstemming met het Groenpact, de tripartiete samenwerking tussen bedrijfsleven, onderwijs en de overheid in het groene domein, die als doel heeft bij te dragen aan een betere aansluiting van het onderwijs op de veranderende arbeidsmarkt en de maatschappelijke opgaven in het groene domein. Wij bedanken de vanuit het Groenpact betrokken deskundigen Christiaan Loef (MinLNV), Laura Roebroeck (Groenpact, Platform Talent voor Technologie), Dick Pouwels (HAS University of Applied Sciences) en Christ Essens (Bestuursbureau Colland), voor hun constructieve bijdrage aan de totstandkoming van dit rapport en de onderliggende classificatie van de groene sector. Wij bedanken ook de leden van de POA Programmacommissie voor hun constructieve feedback op eerdere versies van dit rapport. Tot slot bedanken wij de deelnemers aan de Groenpact Werkconferenties Arbeidsmarkt van 1 november 2019 en 3 november 2020, voor hun vragen en opmerkingen.

We hopen dat de resultaten van dit onderzoek bijdragen aan de bredere dialoog over de ontwikkelingen op de groene arbeidsmarkt.

1 https://www.nro.nl/onderzoeksprogrammas/poa 


\section{Resumé}

Dit rapport bevat de bevindingen van sectorspecifiek onderzoek op basis van bestaande data, naar de aansluiting tussen onderwijs en arbeidsmarkt in de volle breedte van het groene domein. Dit onderzoek biedt daarmee ook een inzicht in wat er met de bestaande data infrastructuur kan worden onderzocht als we de focus leggen op het bestuderen van één specifieke sector. Cruciale stap in dit project was dat wij in overleg met het Groenpact een nieuwe definitie van de groene sector hebben ontwikkeld, waarmee de analyses in dit rapport zijn gedaan. We onderscheiden donkergroene, lichtgroene en niet-groene sectoren, beroepen en opleidingen. Een voorbeeld van een donkergroene opleiding is de wo bachelor in Biotechnologie. Een lichtgroene opleiding kan de hbobachelor opleiding tot vo-docent biologie zijn.

Vanuit de beroepen worden bijvoorbeeld biologen, botanici, zoölogen als donkergroen gezien en diëtisten en voedingsdeskundigen als lichtgroen. Bij de bedrijfssectoren is de Teelt van bloembollen als donkergroen geclassificeerd en de visserij als lichtgroen.

\section{Groei donkergroene opleidingen op ho niveau}

Hoewel het aantal leerlingen dat voor een groene mbo opleiding kiest daalt, neemt het aantal leerlingen in donkergroene opleidingen in het hoger onderwijs nog altijd toe. Dit komt overeen met de algemene trend in het onderwijs en is dus niet sectorspecifiek voor de groene opleidingen.

\section{Toename niet-groene beroepen in donkergroene sector}

We zien een opmars van het aandeel werkenden in niet-groene beroepen in de donkergroene sector, ten koste van het aandeel werkenden in groene beroepen. Daarbij komt van de donkergroen gediplomeerden maar $45-50 \%$ in een groen beroep terecht. Desondanks ervaren zij een relatief hoge mate van subjectieve aansluiting met de arbeidsmarkt. Deze bevindingen vormen een interessante vraag voor nader onderzoek. Van de lichtgroen gediplomeerden komt ongeveer 70\% terecht in een lichtgroen beroep en zij ervaren ook een relatief hoge mate van subjectieve aansluiting op de arbeidsmarkt.

\section{Arbeidsmarkt uitkomsten in groene sector iets minder gunstig}

De groene sector, en met name de donkergroene, lijkt op een aantal arbeidsmarktindicatoren een relatief lager concurrerend vermogen te hebben dan de niet-groene sector. Het loon voor werkenden in loondienst lijkt in donkergroene beroepen achter te blijven op lichtgroene en niet-groene beroepen. Ook volgen werkenden in donkergroene beroepen relatief minder trainingen en besteden ze minder tijd aan informeel leren dan werkenden in lichtgroene en niet-groene beroepen. Daarbij worden donkergroene 
beroepen als het minst complex ervaren en vereisen ze het minste aan multitasking, wat een bekende indicatie is van een vergroot automatiseringrisico.

\section{Weinig mobiliteit in groene sector}

We nemen weinig mobiliteit waar tussen donkergroene, lichtgroene en niet-groene sectoren als men eenmaal aan het werk is. Daarmee lijkt het moment van uitstroom naar de arbeidsmarkt een van de voornaamste momenten die de retentie van mensen beïnvloedt, samen met het moment van doorstromen binnen het onderwijs. 


\section{Inleiding}

De groene sector is cruciaal voor de grote maatschappelijke uitdagingen van dit moment op het gebied van duurzaamheid, gezond en veilig voedsel en een gezonde leefomgeving en natuur. De technologische innovatie en veranderende wet- en regelgeving die hiermee gepaard gaan hebben gevolgen voor de arbeidsmarkt in de groene sector, bijvoorbeeld ten aanzien van de aansluiting tussen onderwijs en arbeidsmarkt, de kwantitatieve vraag naar arbeid en de kwaliteit van het arbeidsaanbod. De tripartiete samenwerking tussen bedrijfsleven, onderwijs en de overheid die als 'Groenpact' bekend staat, heeft als doel bij te dragen aan een betere aansluiting van het onderwijs op de veranderende arbeidsmarkt en de maatschappelijke opgaven in het groene domein. Om dat effectief te doen is het noodzakelijk om beter zicht te krijgen op de arbeidsmarktontwikkelingen in de groene sector.

Om beter zicht te krijgen op de arbeidsmarktontwikkelingen, specifiek in de groene sector, is echter aanvullend onderzoek op basis van bestaande data gewenst, om twee redenen. Ten eerste is het aansturen op nieuwe dataverzameling niet gewenst zolang niet duidelijk is wat de huidige data infrastructuur aan antwoorden kan bieden. Ten tweede biedt het nu lopend Project Onderwijs-Arbeidsmarkt $(\mathrm{POA})^{2}$ weliswaar informatie over groene beroepen en opleidingen, maar is het generieke doel van het POA project om alle arbeidsmarktsectoren in beeld te brengen en het daarvoor gehanteerde aggregatieniveau minder specifiek dan wanneer het doel is om één specifieke sector te bestuderen. De achterliggende data die binnen POA gebruikt worden (bijv. administratieve data van het CBS en enquêtes onder recent gediplomeerden door het ROA en het $(B S)$ bieden echter wel mogelijkheden voor sectorspecifiek aanvullend onderzoek. Appendix A geeft een overzicht van de gebruikte data-bronnen voor de analyses in dit onderzoek.

Dit rapport bevat de bevindingen van dit sectorspecifiek aanvullend onderzoek, naar de aansluiting tussen onderwijs en arbeidsmarkt in de groene sector. In hoofdstuk 2 geven wij een beknopt overzicht van bestaande bronnen die publiceren over arbeidsmarktontwikkelingen in de groene sector, zoals Colland Arbeidsmarkt, Stigas, SBB, ROA en Groenpact. In hoofdstuk 3 tot en met 5 tonen wij de resultaten van ons empirisch onderzoek. Cruciaal hierin is dat wij in overleg met het Groenpact een nieuwe classificatie van de groene sector hebben ontwikkeld. ${ }^{3}$ Alle gepresenteerde cijfers, figuren en tabellen zijn dus maatwerk voor de groene sector, zoals deze in overleg met Groenpact is gedefi-

2 https://roa.maastrichtuniversity.nl/research/research-projects/project-onderwijs-arbeidsmarkt-poa

3 De gevolgde aanpak wordt in hoofdstuk 3 besproken. De classificatie zelf wordt gedocumenteerd in I. Bijlsma, S. Dijksman, D. Fouarge, R. Gerards, S. Steens (2021). Methodiek ROA/Groenpact-classificatie van de groene sector. Maastricht: ROA-TR-2021/1. 
nieerd. Meer over deze maatwerk definitie van de groene sector volgt in hoofdstuk 3 en in een aanvullend technisch rapport waarnaar in hoofdstuk 3 verwezen wordt. 


\section{Analyse van bestaande prognose informatie voor de groene sector}

Ter algemene beeldvorming beginnen wij met een beknopt overzicht van bestaande onderzoeken die arbeidsmarktinformatie over het groene domein publiceren.

\subsection{Colland Arbeidsmarkt}

Colland Arbeidsmarkt is het arbeidsmarkt en ontwikkelingsfonds voor de groene- en agrarische sector. Colland telde eind 2019 een structureel arbeidsvolume van 325.000 arbeidskrachten bij hun aangesloten bedrijven. Ruim de helft hiervan stond op de loonlijst en de andere helft waren zelfstandigen of krachten die niet op de loonlijst stonden. Het structureel arbeidsvolume groeit elk jaar en bevat zowel arbeidskrachten uit bedrijven met als zonder personeel. Colland onderscheidt deze bedrijven in subsectoren, namelijk; bedrijfsvoering, bloembollengroothandel, bos en natuur, dierhouderij, glastuinbouw, hoveniers, loonwerk, open teelt bloembollen, open teelt landbouw, open teelt tuinbouw, open teelt boomkwekerij en paddenstoelenteelt. Van deze subsectoren zijn de hoveniers, glastuinbouw en de loonwerkers het grootst qua omvang (ABF Research, 2018; ABF Research 2020).

Colland publiceert tweejaarlijks een rapport ter ondersteuning van de beleidsdiscussies rondom de groei van de agrarische- en groene sector. Hieronder vatten we een aantal bevindingen samen van de meest recent beschikbare editie (aangevuld met informatie uit eerdere rapporten), die in 2020 door ABF Research is opgesteld in opdracht van Colland, met als thema de staat van de groene- en agrarische arbeidsmarkt. Doel van dit rapport is ondersteuning van beleidsvorming in de agrarische en groene sectoren (ABF Research, 2020). Voor dit rapport maakten ze gebruik van diverse bronnen, waaronder het eigen bedrijvenregister van Colland, CBS microdata met daarin informatie vanuit DUO, de KvK, en van een bedrijvenenquête die ABF Research en Colland door DESAN hebben laten uitvoeren. 5.700 bedrijven hebben vragen beantwoord die dienden als aanvulling op de beschikbare administratieve bronnen (ABF Research 2020).

De cijfers in het rapport gaan specifiek over de bij Colland aangesloten bedrijven en de 14 sub-sectoren waarin deze zijn onderverdeeld. De cijfers omvatten dus niet de gehele sector zoals het CBS deze definieert (ABF Research, 2018, p. 3). Een groot verschil tussen Colland's classificatie van de groene sector en die van het CBS is dat Colland hoveniers wel meetelt en het CBS niet (dat tot de groene sector telt: bosbouw, visserij en landbouw (De Wit, \& van den Beukel, 2019, p. 1)). 
Colland ziet van 2015 tot 2018 een stijging in het aantal bedrijven met werknemers, actief in de agrarische en groene sector. Tussen 2018 en 2019 hebben ze echter een lichte afname van $0,5 \%$ geconstateerd. Desondanks wordt een duidelijke toename in het structurele arbeidsvolume waargenomen tussen 2017 en 2019. Zowel het totaal aantal werknemers op de loonlijst, alsook de totale flexibele schil en het totaal aantal zelfstandigen is toegenomen onder de bedrijven die in het Colland Bedrijvenregister zijn opgenomen (dit zijn alle bedrijven die onder een CAO vallen van de agrarische en groene sectoren die tevens onderdeel uitmaakt van de CAO Colland). Uit het rapport blijkt ook dat werknemers bij de Colland bedrijven veelal mannen zijn ( $73 \%$ tegen 50\% op de totale arbeidsmarkt) met ten hoogste een afgeronde mbo-opleiding ( $75 \%$ tegen $49 \%$ op de totale arbeidsmarkt). Daarnaast is een relatief groot deel niet in het bezit van een startkwalificatie. $23 \%$ van de werknemers bij de Colland bedrijven bezit enkel een basisschool- of vmbo-diploma tegen $12 \%$ op de gehele arbeidsmarkt (ABF Research, 2020). Het rapport toont ook dat $11 \%$ van de werknemers van Colland-bedrijven van Middenof Oost-Europese afkomst is (2\% op de totale arbeidsmarkt) (ABF Research, 2020). Een ander opvallend gegeven is dat de gemiddelde duur van een werkweek in de agrarische en groene sector in vier jaar tijd met 1,4 uur is gestegen naar 29,6 uur in 2019. Deze stijging is niet terug te vinden op de totale arbeidsmarkt waar een gemiddelde werkweek 28,6 uur duurt (ABF Research, 2020).

Verder blijkt uit het rapport dat studenten die voor een opleiding in de groene sector kiezen grotendeels vmbo en mbo studenten zijn. Het aandeel deelnemers aan een groene opleidingen daalt in vergelijking met het totale onderwijs, terwijl het aandeel gediplomeerden gelijk blijft of zelfs toeneemt. De 'groene studenten' uit het hbo of wo komen later relatief minder vaak terecht in de groene sector dan groene studenten uit het mbo ( $47 \%$ voor mbo tegen $27 \%$ hoger onderwijs). Van de groene studenten uit het hoger onderwijs eindigt bijna 1 op de 5 in de sector zakelijke dienstverlening (ABF Research, 2020). Zowel groene mbo- als ho-gediplomeerden werken een half jaar na diplomering voor gemiddeld $20 \%$ (respectievelijk $24 \%$ voor mbo en $17 \%$ voor hoger onderwijs) in de uitzendbranche, wat overigens kan betekenen dat ze via deze weg alsnog werkzaam zijn in de groene sector. Over de jaren heen is echter wel een trend te zien dat gediplomeerden van een groene opleiding (van zowel mbo als ho) steeds meer werkzaam zijn bij bedrijven die niet gelieerd zijn aan Colland.

\subsection{Stigas}

Stigas is het kenniscentrum op het gebied van veilig en gezond werken en duurzame inzetbaarheid voor de agrarische en groene sector en valt net als Colland Arbeidsmarkt onder het Colland samenwerkingsverband van fondsen en regelingen in deze sector. Ze zetten zich in voor duurzaamheid en richten zich op Arbo-gerelateerde diensten, gezondheid en veiligheid in het werkveld. Ze acteren als actieve schakel tussen het daadwerkelijke werk en de wetenschap (Stigas, 2017, p. 2). 
Naar aanleiding van de verhoging van de AOW-leeftijd heeft Stigas (2017) een rapport samengesteld over de huidige staat van duurzaam, veilig en gezond werken binnen de groene- en agrarische sector. Dit met als doel om bij te dragen aan de beleidsdiscussie rondom duurzame inzetbaarheid in de sector. Stigas gebruikt voor hun analyses in dit rapport voornamelijk de bedrijvenregistratie van Colland en cijfers van het CBS en UWV. Het rapport beschrijft hoe een aantal economie-brede ontwikkelingen, zoals de verhoging van de AOW-leeftijd, flexibilisering van de arbeidsmarkt en de vergrijzing, de groene sector treffen.

Van de oudere arbeidskrachten werkt een relatief groot deel door nadat ze de pensioensleeftijd hebben bereikt, gemiddeld $7 \%$ van de veetelers en $10 \%$ van de land- en bosbouwers. Het gemiddelde over alle sectoren is $2 \%$. Inherent aan de groene sector - waarvan delen relatief sterk afhankelijk zijn van de beschikbaarheid van (seizoens) arbeid (bijv. Beldman et al, 2020) - is het hoge aantal flexibele arbeidskrachten. Dit zijn voornamelijk uitzendkrachten. Volgens het rapport neemt het aantal uitzendkrachten nog altijd toe en worden ze voornamelijk ingezet voor fysiek werk in de open teelt, bloembollenhanden en paddenstoelenteel (Stigas, 2017; De Wit, \& van den Beukel, 2019).

Zoals in veel sectoren hebben automatisering en technologische veranderingen een grote impact. Het rapport beschrijft dat eenvoudige, routinematige werkzaamheden kunnen worden overgenomen door machines, bedrijfsvoering kan worden geoptimaliseerd door inzet van moderne technologie en dat dit meer ruimte schept voor cognitief veeleisendere functies (Stigas, 2017, p. 7). Daarbij wordt een behoefte verwacht om die moderne technologie te onderhouden, programmeren en ontwikkelen (Stigas, 2017). Er is in de sector nog ruimte voor innovatie, robotisering en aandacht voor duurzaamheid en bewust produceren. De noodzaak hiervan wordt ook versterkt door bewustwording van consumenten met betrekking tot milieuvriendelijkheid, samen met nieuwe wetgevingen en politieke invloeden hieromheen (Stigas, 2017, p. 7-8; SBB, 2019).

\subsection{UWV}

Het UWV brengt jaarlijks arbeidsmarktprognoses en sectorale factsheets uit. Hierin worden ontwikkelingen op de arbeidsmarkt omschreven en prognoses omtrent vraag en aanbod van arbeid gepresenteerd. In de meest recente arbeidsmarktprognoses (2019) verwachtte UWV dat tussen 2018 en 2020 - van alle sectoren - het aantal banen het meest zou dalen in de sector landbouw, bosbouw en visserij. De verwachting was dat er in 2019 en 2020 gemiddeld per jaar 1.000 banen van werknemers verloren zouden gaan in de sector en 2.000 van zelfstandigen (UWV, 2019, p. 16-18). Voornamelijk het aantal zelfstandigen zou dus verminderen. Volgens de UWV factsheet uit 2019 over de agrarische en groene sector komt de daling in het aandeel zelfstandigen onder meer door technologische innovatie en schaalvergroting. Kleine en middelgrote bedrijven kunnen deze vooruitgang soms niet bijhouden. Ook is het voor veel oudere zelfstandigen moeilijk om een opvolger voor hun bedrijf te vinden. De factsheet benoemt ook 
dat de beroepsbevolking in de groene sector vooral bestaat uit jonge mannen met een middelbare opleiding (De Wit, \& van den Beukel, 2019, p. 1).

\subsection{ROA}

Het Researchcentrum voor Onderwijs en Arbeidsmarkt (ROA) publiceert tweejaarlijks een rapport met prognoses van de arbeidsmarkt naar opleiding en beroep voor het Project Onderwijs Arbeidsmarkt (POA). ROA vermeldt in haar prognoses uit 2019 dat technologische ontwikkelingen als robotisering, innovatie en duurzaamheid naar verwachting tot en met 2024 zullen resulteren in een jaarlijkse krimp van 1,2\% van de werkgelegenheid in de bedrijfssector landbouw, bosbouw en visserij (ROA, 2019, p. 14-15).

Volgens de prognoses lijkt de agrarische sector dus te maken te hebben met een structurele krimp in werkgelegenheid. Deels wordt dit waarschijnlijk opgevangen door natuurlijk verloop, aangezien er tegelijkertijd sprake is van vergrijzing. Vergrijzing en structurele krimp zijn echter geen perfect overlappende fenomenen, waardoor een deel van de banen die vrij komen als gevolg van vergrijzing wel weer ingevuld moeten worden. Ten aanzien van het vinden van geschikt personeel om in deze vervangingsvraag te voldoen, worden in de toekomst voor sommige werkgevers toch problemen verwacht. Met name het aantal afgestudeerden van opleidingen in richtingen als bosbouwer, tuinder, kweker en hovenier zal naar verwachting niet voldoende zijn om de vergrijzing op te vangen. Bij de overige beroepsgroepen lijkt er weinig moeite te zijn bij het vinden van nieuwe (vervangende) arbeidskrachten. Vanuit perspectief van de afgestudeerden van groene opleidingen zijn de arbeidsvooruitzichten goed op mbo-niveau 4 en redelijk op niveaus 2 en 3 . Een grote meerderheid vindt relatief snel een baan. De goede vooruitzichten voor mbo-4 richting voedsel, natuur en leefomgeving komen voornamelijk door de hoge vervangingsvraag dankzij de vergrijzing (ROA, 2019, p. 28). Veel gediplomeerden van een groene opleiding zullen uiteindelijk ook werkzaam zijn in andere sectoren dan waar ze oorspronkelijk voor opgeleid zijn (Motivaction, 2018; ROA, 2019, p. 32-33).

Die uitstroom van landbouw en natuur gediplomeerden naar andere sectoren is een van de trends die te zien is in tabel 1, die een aantal indicatoren toont voor de aansluiting met de arbeidsmarkt (op basis van ONR2019 sub sectoren van het ROA (ROA, 2019, p. 88)). Enkele trends die ongeacht opleidingsniveau gelden voor afgestudeerden met een achtergrond in landbouw en natuur is dat maar weinigen in deeltijd gaan werken, het loon vaak beneden het gemiddelde loon voor het betreffende niveau ligt en men veelal in een baan buiten de eigen richting terecht komt. Een uitzondering hierop zijn de masterstudenten van landbouw en natuur opleidingen, die minder vaak aangeven buiten hun eigen richting te werken (ROA, 2019, p. 39; WUR, 2020). 
Tabel 1

Aansluitingsindicatoren gediplomeerden per niveau van subsector landbouw en natuur ${ }^{4}$

\begin{tabular}{|r|r|r|r|r|r|}
\hline $\begin{array}{r}\text { ONR2019 } \\
\text { Subsector } \\
\text { landbouw en }\end{array}$ & Werkloosheid & $\begin{array}{r}\text { Percentage loon } \\
\text { onder gemiddeld }\end{array}$ & $\begin{array}{r}\text { Onderbenutting (in } \\
\text { hoeverre opleiding } \\
\text { nodig voor de } \\
\text { natuur / niveau }\end{array}$ & $\begin{array}{r}\text { Buiten eigen/ } \\
\text { verwante } \\
\text { richting }\end{array}$ & $\begin{array}{r}\text { Kleine baan (20 } \\
\text { uur of minder) }\end{array}$ \\
\hline Mb0 2 L\&N & $\%$ & $€$ & $\%$ & $\%$ & $\%$ \\
\hline Mb03 3 \&N & 3,9 & 70,9 & 28,5 & 45,7 & 6,0 \\
\hline Mbo 4 L\&N & 3,3 & 78,2 & 34,8 & 40,3 & 6,9 \\
\hline Bachelor L\&N & 0,4 & 76,6 & 27,0 & 38,1 & 5,5 \\
\hline Master L\&N & 5,5 & 66,7 & 21,3 & 24,6 & 2,5 \\
\hline
\end{tabular}

Bron: ROA (2019, p. 88). (AIS)

\subsection{SBB}

De Samenwerkingsorganisatie Beroepsonderwijs Bedrijfsleven (SBB) coördineert het plaatsen van bbl- en bol-leerlingen in het bedrijfsleven voor hun stage of leerbaan. Het SBB publiceert jaarlijks per sector een zogeheten BPV-monitor, wat staat voor Beroeps Praktijk Vorming. Uit de meest recente uitgave (2019) blijkt dat studenten uit de richting 'Voedsel, groen en gastvrijheid' hun beroepspraktijk vorming-periode gemiddeld met een 8 beoordeelden (SBB, 2019).

SBB bekijkt onder anderen ook de Kans op stage en kans op leerbaan voor mbostudenten. Uit het dashboard, met daarin kansen op het vinden van een passende stage of leerbaan (stage bij bol-opleidingen, leerbanen bij bbl-opleidingen), blijkt dat alle getoetste bbl-opleidingen 'voldoende' of 'beter' kansen bieden op een leerbaan. Voor zowel bol- als bbl-opleidingen zijn de goede kansen vooral te vinden in de richting hovenier en medewerker teelt. Onder de bol-opleidingen in groene sector zijn er wel enkele die matige kansen bieden op het vinden van een stage, namelijk de opleidingen in de richting paardensport, medewerker dierverzorging en onderzoeker leefomgeving (SBB, 2019).

SBB verwacht dat het aantal vmbo-leerlingen zal dalen en daarmee (op termijn) ook het aantal mbo-leerlingen. Dit kan problematisch zijn voor de agrarische sector, aangezien deze sector voor een relatief groot aandeel bestaat uit werknemers met een mbo-achtergrond. SBB verwacht, vooral in hoogconjunctuur, een stijgend tekort aan mbo-krachten en stelt dat het aantal mbo-vacatures in de groene sector stijgt, vooral bij hoveniersbedrijven, de bloemensector en boomkwekerijen. Nu al zijn er hoveniers en groenvoorzieners die kampen met personeelstekorten. Ook is er steeds meer technisch-geschoold mbo-personeel nodig. Door de robotisering en automatisering komen er namelijk steeds meer machines en technologieën die het productieproces automatiseren en rekening houden met duurzaamheid en ecologie. Ook is sprake van nieuwe technolo-

4 Cijfers uit 2016/2017, voor wo uit 2015/2016. Bron: ROA (2019, p. 88). (AIS). 
gieën zoals bijvoorbeeld gps in het loonwerk voor precisielandbouw. Er is behoefte aan personeel dat kan omgaan met deze vernieuwingen. Dit vereist dus andere competenties van werknemers die eerst niet of in mindere mate nodig waren.

Tot slot lichten we hier enkele ontwikkelingen eruit die SBB ziet als gevolg van de vergrijzing. De vergrijzing versterkt de vraag naar nieuw personeel en gaat volgens SBB gepaard met een behoefte aan nieuwe kennis die de bedrijven middels werving kunnen binnen halen. Ook brengt de vergrijzing kansen met zich mee, zoals het veranderen of uitbreiden van bedrijfsmodellen meer gericht op duurzame en omvangrijkere producties. Deze uitbreiding wordt ook gedreven door de trend van schaalvergroting. De oppervlakte grond per bedrijf groeit omdat er relatief steeds minder bedrijven zijn, wat ruimte biedt om het bestaande bedrijf te laten groeien of om de activiteiten uit te breiden. Zulke activiteiten kunnen bijvoorbeeld een camping of boerderijwinkel zijn. Biologisch eten en duurzaamheid zijn trends waar consumenten steeds meer in geïnteresseerd zijn, een boerderijwinkel is bijvoorbeeld een manier waardoor ondernemers op die trends kunnen inspelen (SBB, 2019).

\subsection{Groenpact}

In opdracht van Groenpact heeft Motivaction onderzocht wat mogelijke motivaties kunnen zijn voor jongeren om een groen-gerelateerde opleiding te kiezen. Door middel van focusgroepen en survey-data concluderen zij drie groepen jongeren; technologie-minded jongeren, breed georiënteerde jongeren en terughoudende jongeren. Motivaction omschrijft voor deze groepen verschillende actiepunten die zouden kunnen helpen als stimulans om te kiezen voor een groene opleiding. Een actiepunt wat veel wordt gesuggereerd is het benadrukken van het brede karakter van de groene sector. Andere opties zijn aandacht besteden aan het technologische aspect, maar ook aan het maatschappelijke en sociale belang van de groene sector. Een modern beeld hebben van de veelzijdigheid van de groene sector is essentieel voor jongeren, omdat de agrarische sector momenteel niet als de meest aantrekkelijke sector wordt gezien door jongeren (Boerderij, 2018; Motivaction, 2018).

\subsection{Overeenkomsten en blinde vlekken bestaand arbeidsmarktonderzoek groene sector}

Door de dynamische groei van de sector missen huidige onderzoeken veelal een eenduidige definitie en afbakening van zowel opleidingen, als beroepen, als bedrijven in de groene sector. De meest leidende richtlijnen in Nederland lijken de bedrijvenregistratie van Colland en de SBI-codes van het CBS. Tabel 2 toon een overzicht van de tot nu toe besproken bronnen en de bijbehorende dekking van de groene sector, die sterk wisselt tussen de verschillende onderzoeken. Dit leidt ook tot een aantal op het eerste oog tegenstrijdige bevindingen, die echter een reflectie zijn van de verschillende 
definities van wat de groene sector behelst. Zo vermeldt Colland dat de groene- en agrarische sector nog altijd groeit qua vacatures en structureel arbeidsvolume, hoewel de groei tijdens het eerste half jaar van 2020 wat achter bleef vergeleken met de groei van voorgaande jaren (ABF Research, 2020). Uit de data die ROA gebruikt, blijkt dat de agrarische sector van 2015 tot en met 2017 inderdaad enigszins is aangetrokken, maar dat er richting de toekomst een daling in werkgelegenheid in de sector verwacht wordt. Dit zijn echter prognoses. Onvoorziene ontwikkelingen, zoals bijvoorbeeld een pandemie of effecten van de groene transitie, kunnen de realiteit anders doen uitpakken, maar ook het publiceren van prognoses kan ertoe leiden dat er aanpassingsmechanismes op de arbeidsmarkt in werking treden, die ervoor kunnen zorgen dat prognoses geen werkelijkheid worden. Een van de belangrijkste bijdragen van het onderzoek dat u nu voor zich heeft, is dan ook dat we samen met het Groenpact gekomen zijn tot een nieuwe definitie van de groene sector, zowel qua opleidingen, beroepen als qua bedrijfssectoren. Alle analyses die in de volgende hoofdstukken aan bod komen, zijn uitgevoerd op basis van deze nieuwe met Groenpact opgestelde definitie van de groene sector. 


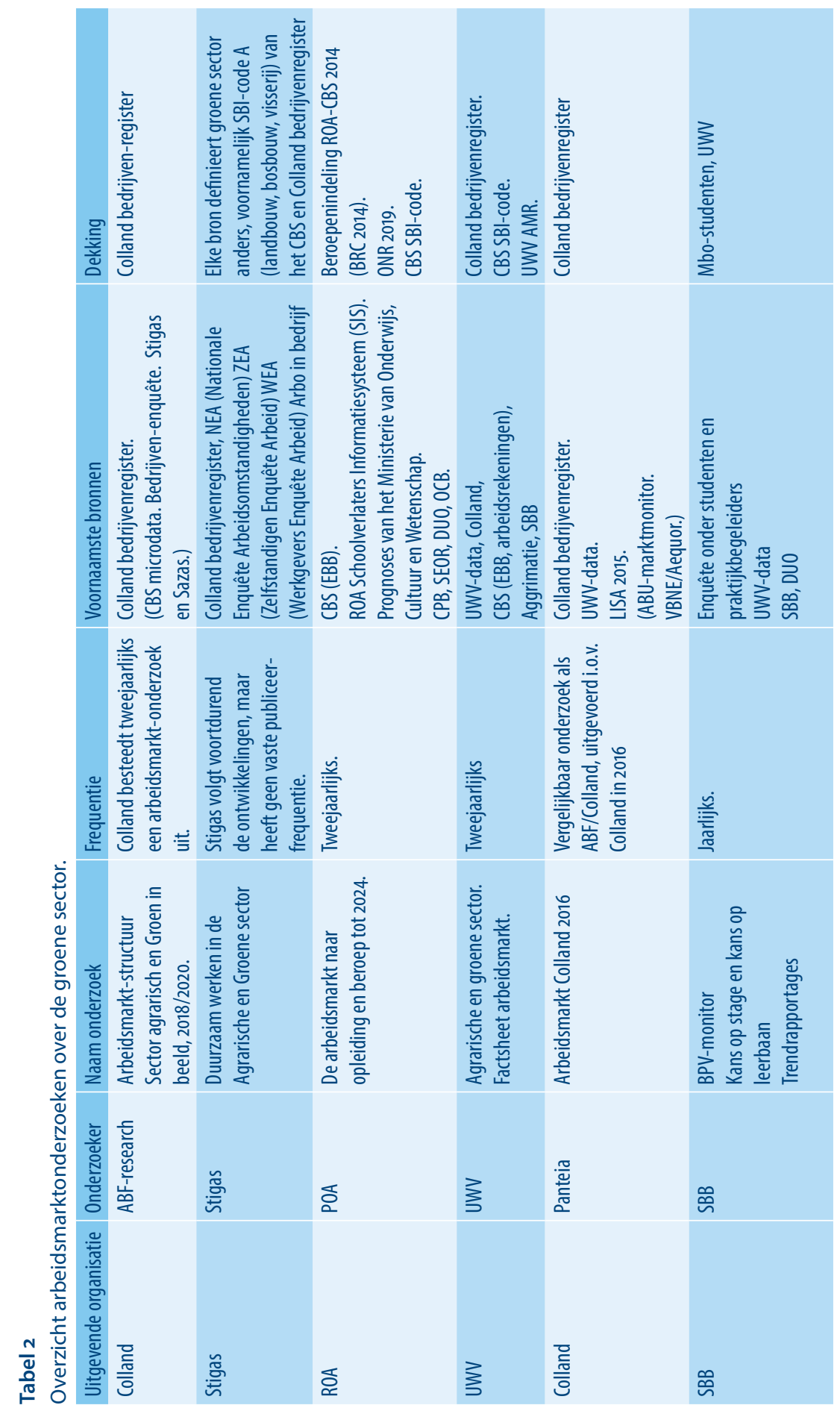




\section{Verdiepende analyses van de overgang van onderwijs naar arbeidsmarkt in de groene}

sector

\subsection{Ontwikkeling classificatie groene sector i.s.m. Groenpact}

Om tot een arbeidsmarktmonitor voor de Groene sector te kunnen komen is het essentieel om een duidelijke definitie van de groene sector te hanteren. Daarom heeft het ROA samen met Groenpact alle Nederlandse opleidingen, beroepen en bedrijfssectoren op de kleinste aggregatieniveaus ingedeeld tot een nieuwe definitie van de groene sector. Daarbij hebben alle opleidingen beroepen en bedrijfssectoren benoemd als 'donkergroen', 'lichtgroen' of 'niet-groen'. Allereerst een selectie van opleidingen, bedrijfssectoren en beroepen in de voornaamste 'donkergroene' schil, en daaromheen een selectie van opleidingen, bedrijfssectoren en beroepen in een 'lichtgroene' schil. Deze twee schillen kunnen apart in berekeningen in beeld worden gebracht, maar ook worden opgeteld tot een totale groene sector (Groenpact, 2020). Een grafische weergave hiervan staat in figuur 1 .

\section{Figuur 1}

Overzicht totstandkoming classificatie

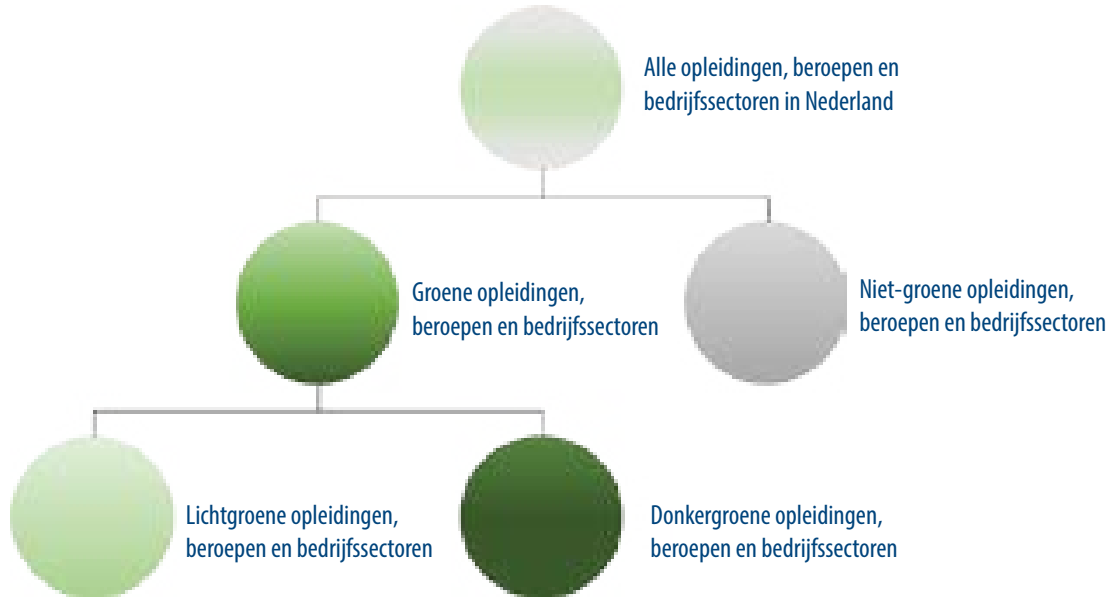

Een overzicht van de gebruikte classificaties en hun aggregatieniveaus is weergegeven in tabel 3. Voor meer informatie over de volledige totstandkoming van deze classificatie 
verwijzen wij graag naar Methodiek ROA/Groenpact-classificatie van de groene sector ${ }^{5}$ waar het gehele proces staat gedocumenteerd. Als voorbeeld vatten we hieronder kort samen wat globaal de criteria waren voor de indeling van de opleidingen. Opleidingen die specifiek worden aangeboden ten behoeve van de primaire sectoren (land- en tuinbouw), voedsel en natuur zijn als donkergroen geclassificeerd. Deze opleidingen worden aangeboden door het groen onderwijs6 en zijn geregistreerd in het groene domein7. Andere opleidingen die passen in het groene landschap zijn als lichtgroen geclassificeerd. Dit betreft bijvoorbeeld opleidingen op het vlak van food (industrie, vers logistiek/handel, retail, service/horeca) of op het vlak van technologie, water en milieu. Tabel 4 toont vanaf mbo-niveau 2 (niveau van startkwalificatie) hoeveel opleidingen er als donkergroen, lichtgroen en niet-groen geclassificeerd zijn volgens deze nieuwe definitie (wanneer gekoppeld aan DUO-data). Deze aantallen betreffen zowel actuele als historische opleidingsnummers. Een volledig overzicht van de gebruikte databronnen voor de analyses in dit rapport staat in appendix A.

Tabel 3

Overzicht classificaties en gebruikte aggregatieniveaus.

\begin{tabular}{l|l|l|}
\hline Sectoronderdeel & Classificatie & Aggregatieniveau \\
\hline Opleidingen & ONR2019 & CREBO/CROHO \\
\hline Bedrijfssectoren & SBI2008 & 5-cijferige SBI-code \\
\hline Beroepen & BRC2014 & ISCO-code
\end{tabular}

Tabel 4

Aantallen opleidingen, naar groen classificatie en niveau

\begin{tabular}{|l|r|r|r|}
\hline & \multicolumn{3}{|c|}{ Aantal opleidingen } \\
Niveau & Donkergroen & Lichtgroen & Niet-groen \\
\hline Mb02 & 114 & 42 & 912 \\
\hline Mb03 & 188 & 55 & 1.033 \\
\hline Mb04 & 220 & 82 & 1.193 \\
\hline Hbo ad & 18 & 4 & 252 \\
\hline Hbo-bachelor & 97 & 24 & 1.116 \\
\hline Hbo-master & 20 & 6 & 300 \\
\hline Wo-bachelor & 25 & 7 & 251 \\
\hline Wo-master & 134 & 52 & 1.472 \\
\hline
\end{tabular}

\subsection{Ontwikkeling in het aantal deelnemers in groen onderwijs}

Op basis van data van DUO over de instroom van deelnemers aan het onderwijs is het mogelijk om de ontwikkeling van het aantal deelnemers over de tijd weer te geven.

5 I. Bijlsma, S. Dijksman, D. Fouarge, R. Gerards, S. Steens (2021). Methodiek ROA/Groenpact-classificatie van de groene sector. Maastricht: ROA-TR-2021/1.

6 Onderwijs dat tot en met 2017 door het ministerie van LNV werd bekostigd

7 Centraal Register Beroepsopleidingen (Crebo domein Voedsel, Natuur en Leefomgeving), Centraal Register Opleidingen Hoger Onderwijs (Croho domein Landbouw \& Natuurlijke Omgeving). 
Figuur 2 toont dat het aantal deelnemers in groene ho-opleidingen de afgelopen jaren is toegenomen en voor groene mbo-opleidingen is afgenomen. Het aantal deelnemers in donkergroene mbo-opleidingen daalt al geruime tijd en in lichtgroene mbo-opleidingen is de daling recenter ingezet. Echter, zowel de daling in het mbo als de stijging in het hoger onderwijs, vinden niet alleen plaats in de groene sector, maar zien we ook bij niet-groene opleidingen.

\section{Figuur 2}

Aantallen deelnemers in groene opleidingen, 2006-2020.

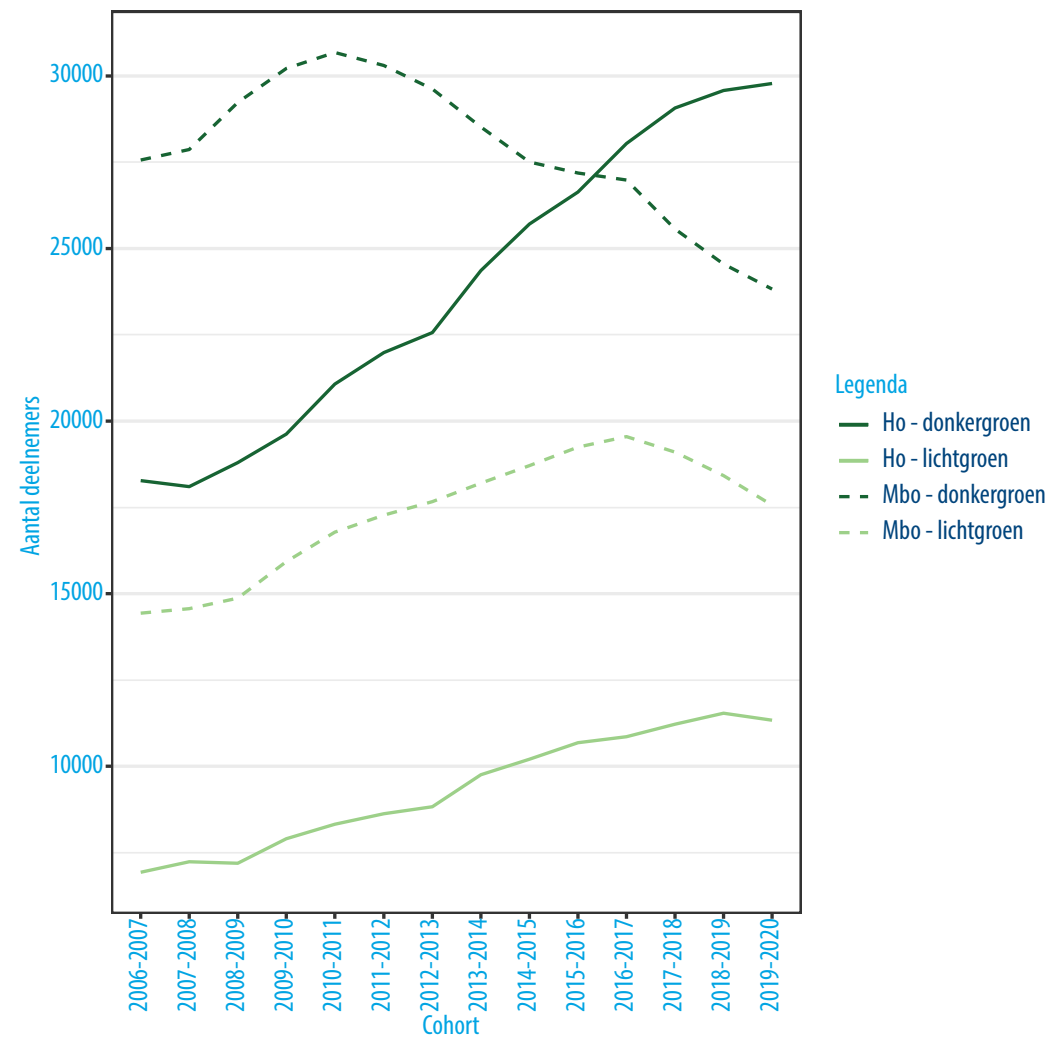

Bron: DUO data, bewerking ROA

Kijken we nader naar de lichtgroene mbo-opleidingen, dan zien we in figuur 3 dat er (tot cohort 2017-2018) een sterke stijging plaats heeft gevonden in het aantal deelnemers aan lichtgroene mbo3- en 4 opleidingen. Het aantal deelnemers in mbo2 opleidingen daalt echter al geruime tijd aanzienlijk. Dit is overigens ook het geval bij donkergroene en niet-groene mbo2 opleidingen. Dit onderstreept de hypothese dat er steeds meer sprake is van 'upgrading' op de arbeidsmarkt. De vraag naar hoogopgeleiden op de arbeidsmarkt neemt sterk toe, onder meer doordat er voor veel functies een 
steeds hoger niveau diploma wordt gevraagd. Het aanbod van hoogopgeleiden op de beroepsbevolking stijgt echter ook, hoewel dit minder sterk stijgt dan de vraag hiernaar (OECD, 2014; Fouarge, 2017).

\section{Figuur 3}

Deelnemers in lichtgroene mbo-opleidingen 2006-2020.

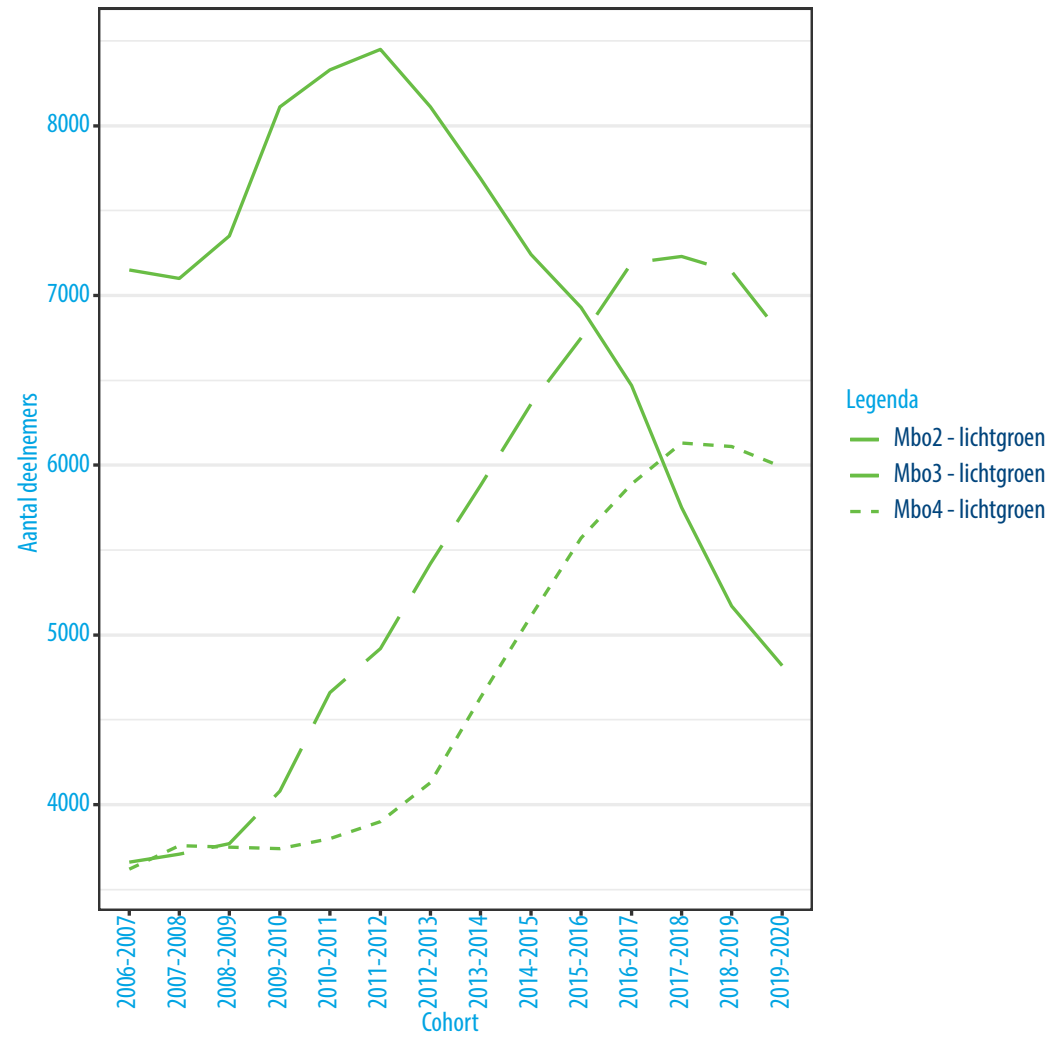

Bron: DUO data, bewerking ROA

\subsection{Ontwikkeling in aantal gediplomeerden van groen onderwijs}

De data van DUO kan ook worden gebruikt om de ontwikkeling van het aantal gediplomeerden in beeld te brengen. Uit figuur 4 kan worden opgemaakt dat het aantal gediplomeerden in de groene sector stijgt op zowel ho- als mbo-niveau. Opvallend is echter dat het aantal deelnemers in donkergroene mbo-opleidingen al geruime tijd daalt (figuur 2), terwijl er een toename in gediplomeerden is. Om de piek in 2016-2017 te verklaren, kijken we in figuur 5 naar de verdeling van donkergroene mbo-gediplomeerden naar niveau. 


\section{Figuur 4}

Gediplomeerden in groene opleidingen 2006-2019

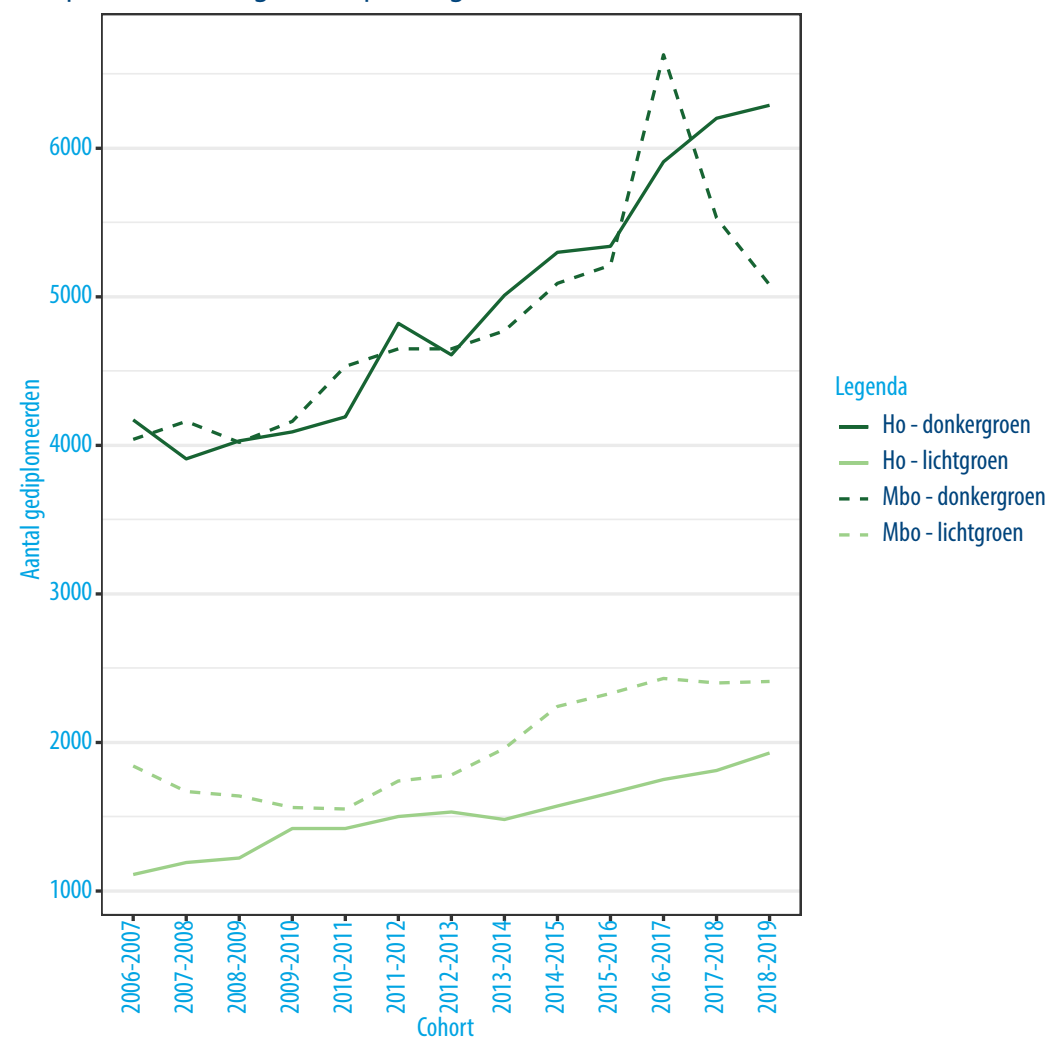

Bron: DUO data, bewerking ROA

Figuur 5 toont dat een toename in gediplomeerden van donkergroene mbo 4 opleidingen de oorzaak is van de piek in cohort 2016-2017. Een verklaring voor deze piek kan de invoering van de wet Doelmatige Leerwegen zijn (NRO, 2018; Wielenga-van der Pijl, Van der Mooren, \& Pleijers, 2019). Met ingang van cohort 2014-2015 heeft deze wet de duur van een mbo 4 opleidingen verkort van 4 naar 3 jaar. Er zijn enkele uitzonderingen die nog steeds 4 jaar duren, maar de norm is een middenkaderopleiding met een duur van 3 jaar. Dit betekent dat zowel cohort 2014-2015 (een 3-jarige opleiding na invoering van wet Doelmatige Leerwegen) als 2013-2014 (nog een 4-jarige opleiding voor invoering van wet Doelmatige Leerwegen) hun diploma hebben behaald in 2016-2017. Verder schommelt het aantal gediplomeerden uit donkergroene mbo 2 en 3 opleidingen, maar met een licht stijgende trend over de hele periode. 


\section{Figuur 5}

Gediplomeerden in donkergroene mbo-opleidingen 2006-2019

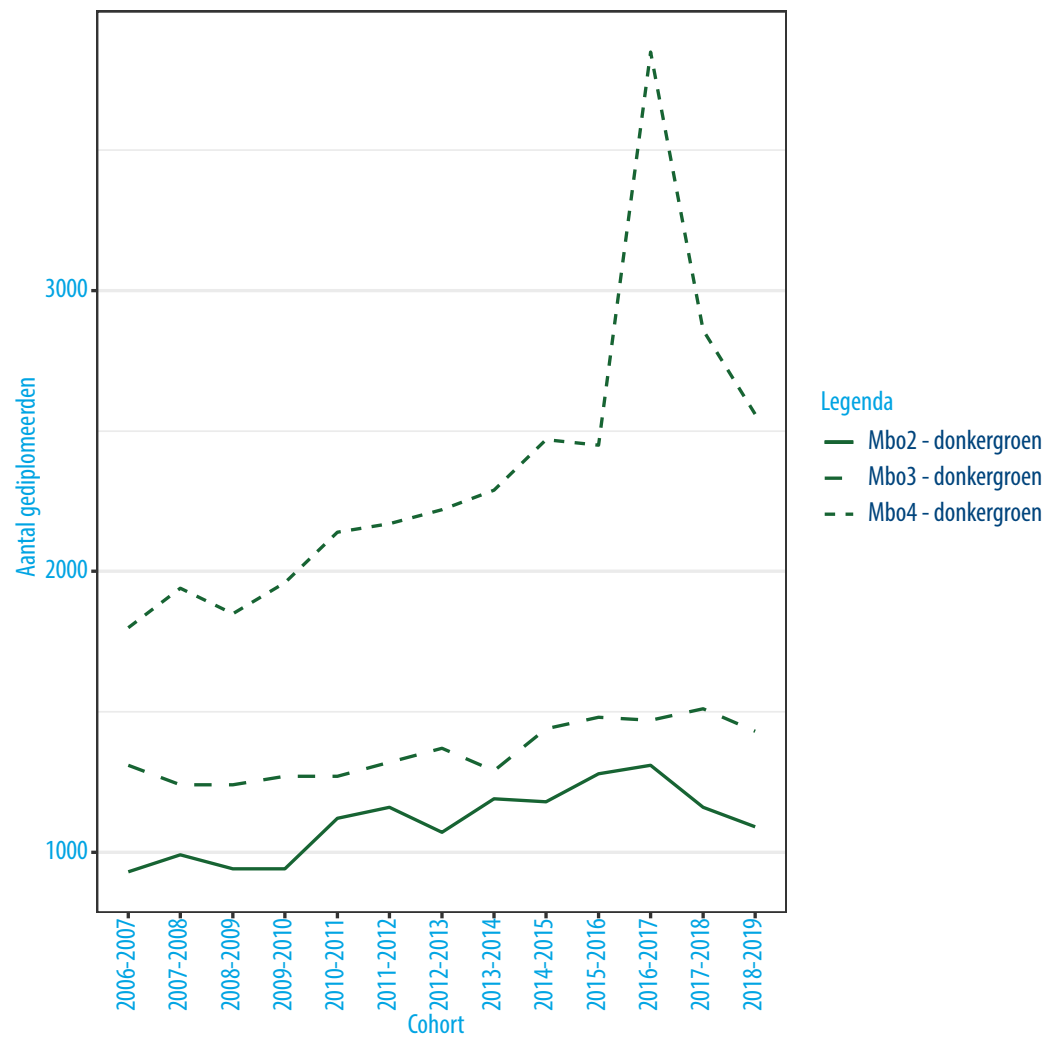

Bron: DUO data, bewerking ROA

\subsection{Het rendement van groene opleidingen in termen van doorstroom- en arbeidsmarktuitkomsten}

Om het 'rendement' van groene opleidingen in beeld te brengen kijken we in deze paragraaf naar de doorstroom van gediplomeerd en naar de arbeidsmarktuitkomsten van gediplomeerden 1, 2 en 5 jaar na diplomering. Om uitspraken te doen over 5 jaar na diplomering, moeten we terug gaan naar cohort 2012-2013. Dit is het meest recente cohort gediplomeerden waarvoor deze arbeidsmarktinformatie tot 5 jaar na afstuderen beschikbaar is. Omwille van consistentie, tonen we alle figuren in deze paragraaf op basis van dit cohort 2012-2013.

\subsubsection{Doorstroom naar een andere opleiding na behalen van een 'groen diploma'}

Met het analyseren van de doorstroom van gediplomeerden van groene opleidingen kunnen we een beeld krijgen welk niveau en type opleiding (lichtgroen of donkergroen) 
relatief vaak tot verder leren leidt en dus ook welk niveau en type groene opleiding relatief minder tot doorstroom leidt, en dus hoogstwaarschijnlijk tot toetreding op de arbeidsmarkt.

Van cohort 2012-2013 koos gemiddeld 33\% van álle mbo-gediplomeerden (dus groen én niet-groen) om door te studeren. Gediplomeerden van donkergroene mbo-opleidingen studeerden minder dan gemiddeld door (26.2\%) en van lichtgroene mbo-opleidingen meer dan gemiddeld (38.1\%). Gediplomeerden van niet-groene opleidingen zaten precies op de gemiddelde doorstroom (33.2\%). Dit zou erop kunnen duiden dat donkergroene mbo-opleidingen een bovengemiddelde en lichtgroene mbo-opleidingen een ondergemiddelde aansluiting met de arbeidsmarkt kenden (voor dit cohort). De lichtgroene gediplomeerde koos immers vaker voor doorstuderen dan de donkergroene gediplomeerde. Een volledig tabel met doorstroompercentages naar niveau en richting is vanwege de omvang opgenomen in Appendix B.

In figuur 6 zoomen we verder in op die gediplomeerden van groene mbo-opleidingen die doorstromen. We kijken hier alleen naar doorstromers waarvan bekend is dat ze later ook daadwerkelijk nog een ander diploma behaalden. Doorstromers die vervolgens tot op heden geen diploma meer hebben gehaald zijn hierin niet meegenomen.

Figuur 6 toont dat de doorstromers vooral kozen voor een opleiding op een hoger niveau. Vanuit een donker- of lichtgroene mbo2 en mbo3 opleiding kozen doorstromers merendeels voor een vervolgopleiding in dezelfde richting op een hoger niveau. De doorstroom vanuit mbo4-opleidingen vertoont meer versnippering. Gediplomeerden hiervan stroomden ook voornamelijk door naar een hoger niveau, maar dat was wel relatief vaak naar een niet-groene opleiding. 


\section{Figuur 6}

Doorstroom gediplomeerden van groene mbo-opleidingen, (cohort 2012-2013)

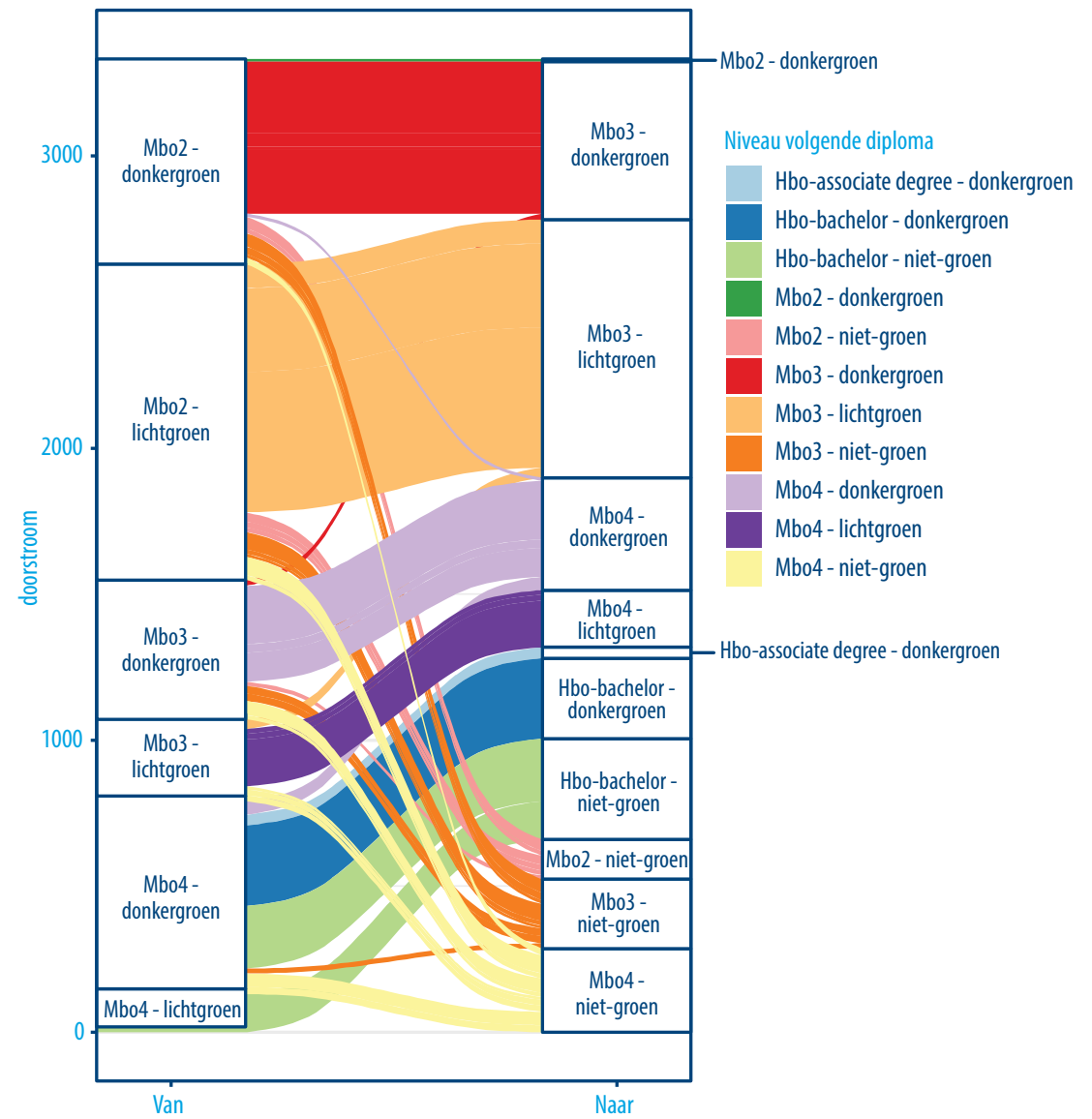

Bron: CBS microdata, bewerking ROA

Noot: We kijken naar gediplomeerden van voltijd opleidingen, die daadwerkelijk nog een ander diploma behaalden. Diegenen die doorstroomden en zijn uitgevallen zijn niet meegenomen.

Wat betreft de ho-gediplomeerden van cohort 2012-2013, besloot in totaal $28.8 \%$ om door te studeren. Ho-gediplomeerden van groene opleidingen (32.3\% voor donkergroen en $29.6 \%$ voor lichtgroen) studeerden vaker door dan van niet-groene ho-opleidingen (28.6\%). Het verschil is het grootst tussen gediplomeerden van donkergroene en niet-groene opleidingen, wat erop zou kunnen wijzen dat met name donkergroene ho-opleidingen (destijds) een iets mindere aansluiting met de arbeidsmarkt kenden.

Figuur 7 toont analoog aan figuur 6 de doorstroom vanuit licht- en donkergroene opleidingen uit het hoger onderwijs. Het aantal doorstromers in het groene hoger onderwijs vertoont gelijksoortige trends als de doorstroom in het mbo uit figuur 6. De meeste donkergroene doorstromers blijven binnen hun domein, maar gaan naar een hoger 
niveau. Ook lichtgroene doorstromers gaan voornamelijk naar een hoger niveau, maar net als de lichtgroene mbo-doorstromers ook relatief vaak naar niet-groene opleidingen.

\section{Figuur 7}

Doorstroom gediplomeerden van groene ho-opleidingen, (cohort 2012-2013)

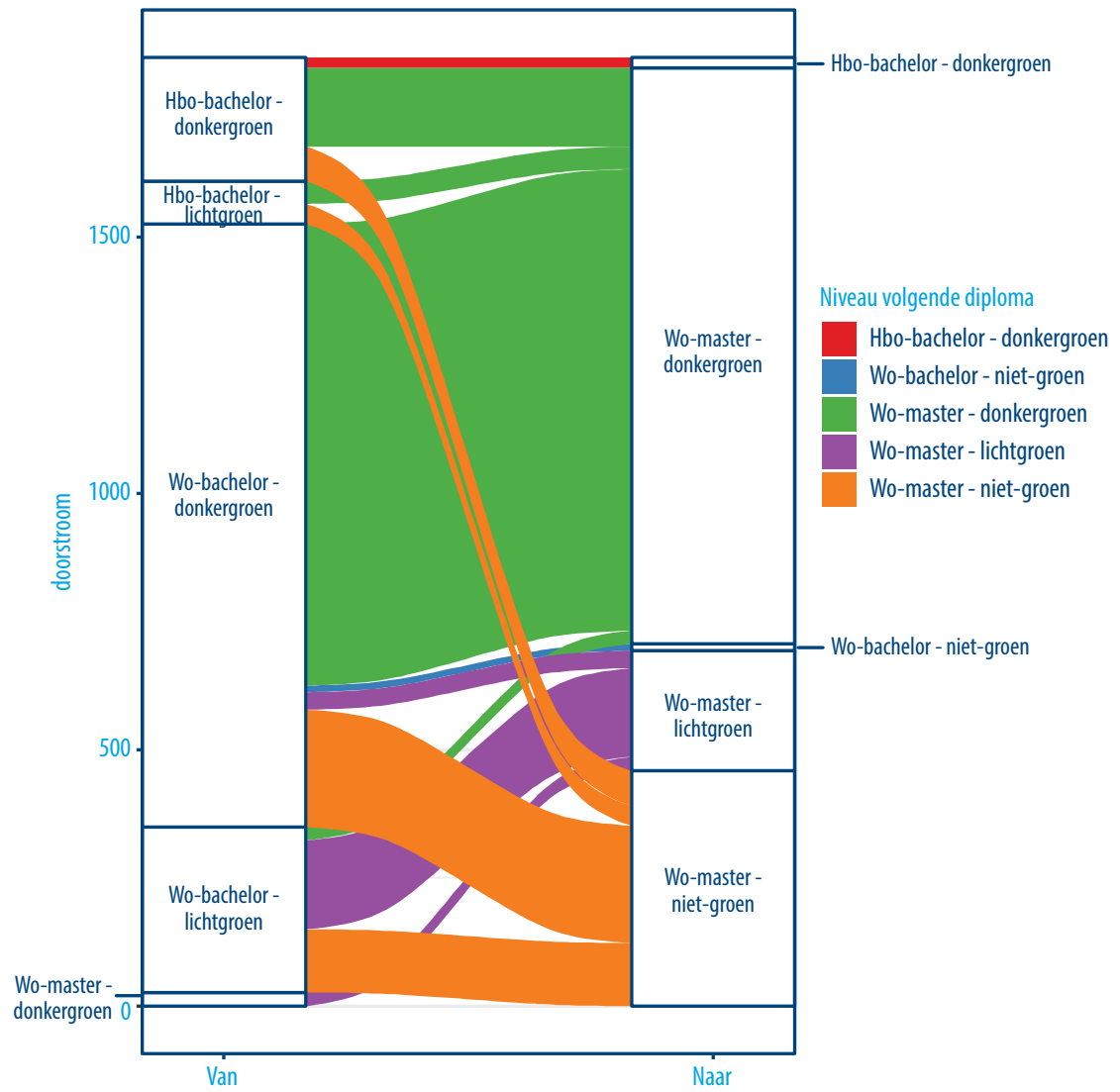

Bron: CBS microdata, bewerking ROA

Noot: We kijken naar gediplomeerden van voltijd opleidingen, die daadwerkelijk nog een ander diploma behaalden. Diegenen die doorstroomden en zijn uitgevallen zijn niet meegenomen.

\subsubsection{Ontwikkeling op de arbeidsmarkt na diplomering}

\section{De arbeidsmarktpositie 1, 2 en 5 jaar na diploma}

Op het moment dat gediplomeerden besluiten niet (op korte termijn) verder in het onderwijs door te stromen betreden ze de arbeidsmarkt. Figuur 8 toont op basis van persoonsgegevens van het CBS de positie op de arbeidsmarkt van voltijds mbo-gediplomeerden die in cohort 2012-2013 hun (tot op heden) laatste diploma hebben behaald. Tussen de gediplomeerden van lichtgroene en niet-groene mbo-opleidingen zit weinig verschil in arbeidsmarktpositie 1, 2 en 5 jaar na diplomering. Meest opvallend is dat gedi- 
plomeerden van donkergroene mbo-opleidingen relatief vaker ingeschreven zijn als zelfstandige. Dit aandeel groeit nog eens aanzienlijk tussen 2 en 5 jaar na diplomering. Waar het percentage dat als werknemer geregistreerd staat toeneemt over tijd bij lichtgroen en niet-groen gediplomeerden, komt dit bij donkergroen-gediplomeerden tot uitdrukking in het percentage zelfstandigen. De uitkeringsafhankelijkheid toont weinig verschil over de jaren en tussen de richtingen.

\section{Figuur 8}

Arbeidsmarktpositie van mbo-gediplomeerden 1, 2 en 5 jaar na diplomering, (Cohort 20122013)

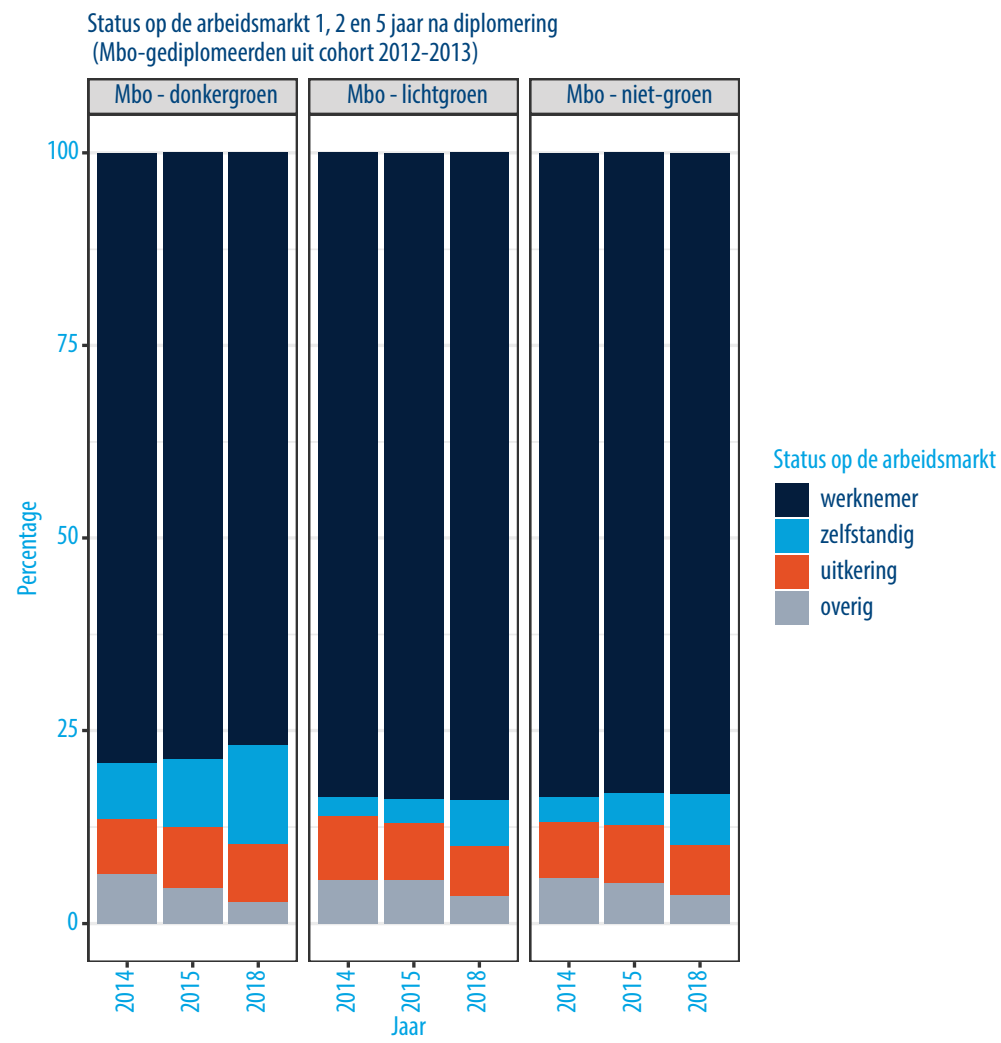

Bron: CBS microdata, bewerking ROA

Figuur 9 toont de arbeidsmarktpositie 1, 2 en 5 jaar na diplomering voor voltijds ho-gediplomeerden. Ook in het hoger onderwijs zijn de verschillen vooral waar te nemen in de ontwikkelingen van de donkergroen-gediplomeerden. Het aandeel zelfstandigen is groter bij donkergroen-gediplomeerden en groeit relatief sterk. Het is ook opvallend dat het aandeel 'overig' groter is. Dit zijn mensen die geen (geregistreerd) inkomen of een uitkering ontvangen. Wel halveert het aandeel gediplomeerden in deze categorie 
vijf jaar na diplomering, maar het blijft iets groter dan bij lichtgroen en niet-groen gediplomeerden. Wellicht is het iets moeilijker voor donkergroene ho-gediplomeerden om (meteen) na diplomering een baan te vinden.

\section{Figuur 9}

Arbeidsmarktpositie van ho-gediplomeerden 1, 2 en 5 jaar na diplomering, (Cohort 2012-2013)

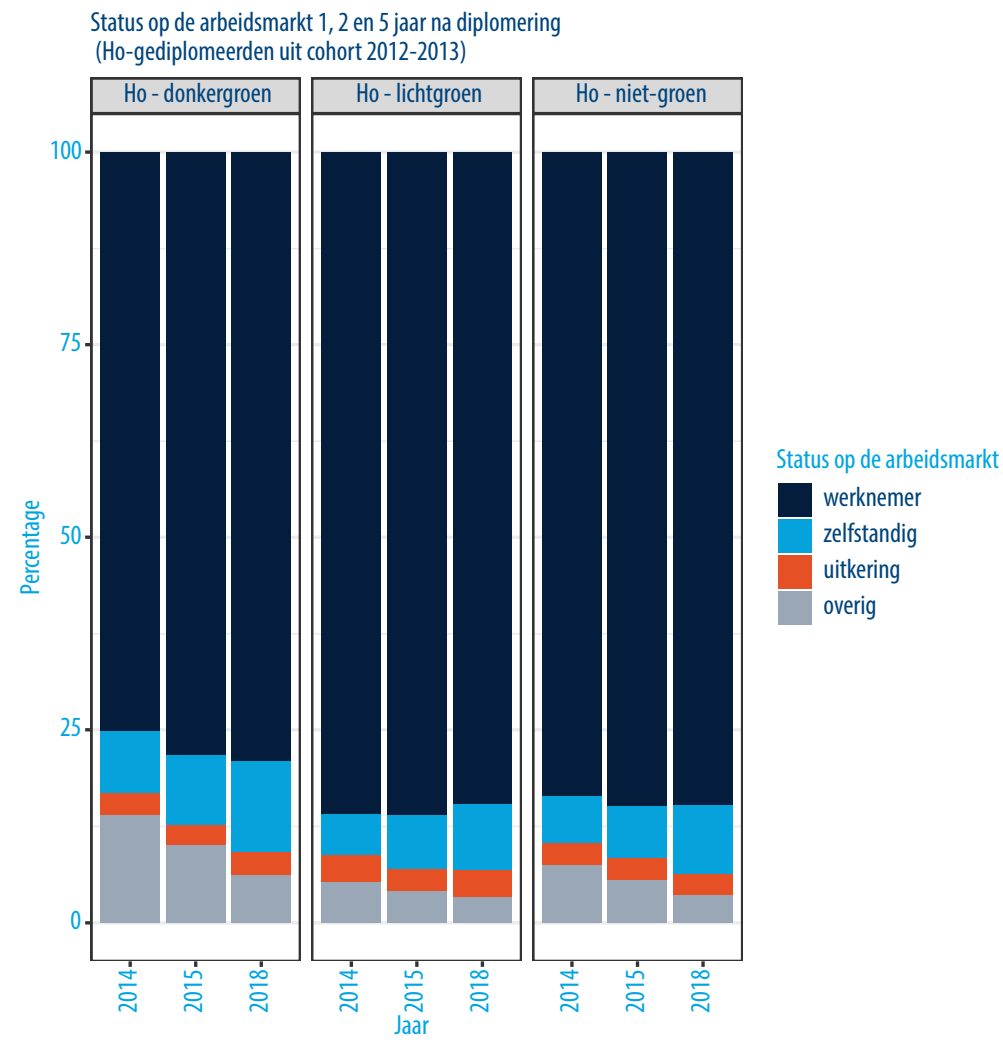

Bron: CBS microdata, bewerking ROA

Tabel 5 toont de kans op werk en het uurloon van gediplomeerden van cohort 20122013, gemeten op 31 december van 2014, 2015 en 2018 (1, 2 en 5 jaar na diplomering). We onderscheiden natuurlijk het type opleiding (donkergroen, lichtgroen en niet-groen), het niveau en het geslacht. De kans op werk wordt gedefinieerd als het percentage gediplomeerden dat ofwel werknemer ofwel zelfstandig is. Het gemiddelde bruto uurloon is gebaseerd op de deling van het belastbaar loon door het aantal verloonde uren van werknemers. Deze loon-informatie is in deze vorm niet beschikbaar voor zelfstandigen.

8 In Appendix C staan deze figuren inclusief de categorieën 'niet in SECM' (niet aanwezig in de Nederlandse register-data) en 'student/scholier'. 
Eén jaar na diplomering verdienen mannen vanuit een lichtgroene ho-opleidingsrichting het meest, gevolgd door mannen vanuit een niet-groene ho-opleiding. De vrouwen uit deze zelfde opleidingsrichtingen volgen hierna, samen met de mannen uit een donkergroene ho-opleiding. Op lange termijn ( 5 jaar na diplomering) verdienen mannen uit het hoger onderwijs het meest. Het hoogste uurloon verdienen mannen uit een niet-groene ho-opleidingsrichting, gevolgd door mannen een lichtgroene- en donkergroene ho-opleidingsrichting.

Een jaar na diplomering zijn mannen met een donkergroen mbo-diploma vaker aan het werk dan mannen uit een niet-groene of lichtgroene opleiding. Dat komt vooral doordat mannen met een donkergroene mbo-opleiding relatief vaak al binnen een jaar als zelfstandige aan de slag zijn.

Voor zowel mannen als vrouwen van mbo-opleidingen zien we de kans op werk in de loop der jaren toenemen, zowel als werknemers en als zelfstandige. De kans op werk van ho gediplomeerden neemt over tijd nauwelijks toe, maar hun kans op werk is over het algemeen het eerste jaar na diplomering al hoog. Uitzondering zijn de ho donkergroen gediplomeerden die één jaar na diplomering een lagere kans op werk hebben dan andere ho gediplomeerden en hun kans op werk ook weinig zien stijgen. Vijf jaar na diplomeren hebben donkergroene ho-opgeleiden daarmee een stuk lagere kans op werk dan donkergroene mbo-opgeleiden.

In appendix $D$ is deze tabel verder uitgesplitst naar BBL of BOL-opleiding. BBL-gediplomeerden verdienen structureel meer dan BOL- gediplomeerden, dit verschil is het grootst bij donkergroene mbo-gediplomeerden (tot ruim $€ 5,30$ per uur). 


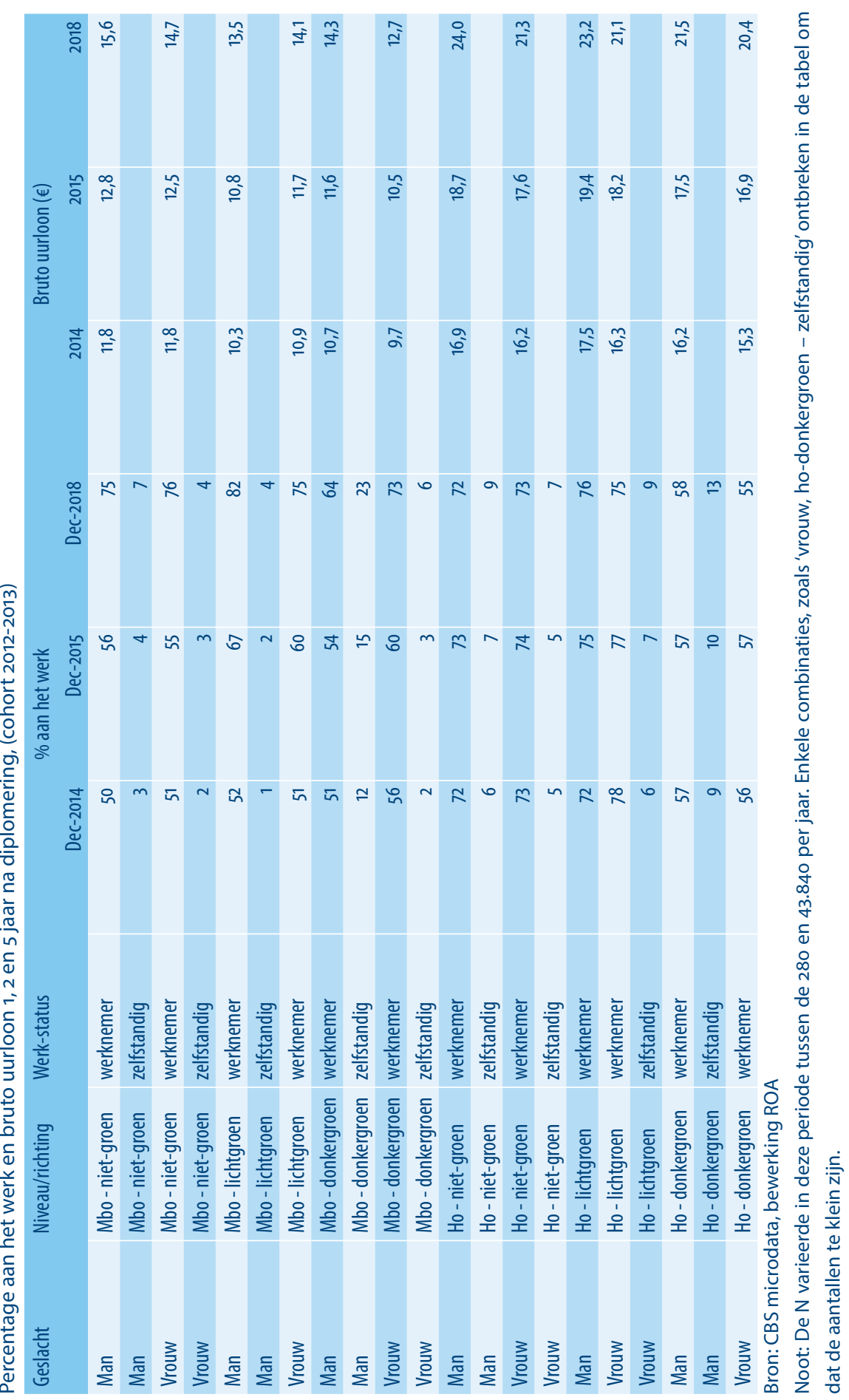


Hoe ervaren gediplomeerde de aansluiting tussen onderwijs en arbeidsmarkt?

In tabel 6 gaan we nader in op hoe afgestudeerden op de arbeidsmarkt terecht komen. Op basis van data uit het ROA Schoolverlaters Informatie Systeem (SIS) ${ }^{9}$ en de Nationale Alumni Enquête $(\mathrm{NAE})^{10}$ tonen we voor afgestudeerden die anderhalf jaar na diplomering zijn bevraagd in 2008, 2013 en 2018 het werkloosheidspercentage, het percentage dat aangeeft op eigen niveau en het percentage dat aangeeft in eigen richting te werken.

\section{Tabel 6}

Werkloosheid en aansluiting qua niveau/richting, naar jaar, niveau en richting

\begin{tabular}{|c|c|c|c|c|}
\hline Opleidingsniveau & Jaar & $\%$ Werkloos & \% Eigen niveau & \% Eigen richting \\
\hline Mbo2 - donkergroen & 2008 & 2,9 & 74,6 & 49,4 \\
\hline Mbo2 - donkergroen & 2013 & 9,6 & 67,1 & 58,5 \\
\hline Mbo2 - donkergroen & 2018 & 6,6 & 70,2 & 51,4 \\
\hline Mb02 - lichtgroen & 2008 & 1,7 & 79,6 & 76,1 \\
\hline Mb02 - lichtgroen & 2013 & 6,9 & 53,1 & 78,2 \\
\hline Mb02 - lichtgroen & 2018 & 3,1 & 76,0 & 61,5 \\
\hline Mb02 - niet groen & 2008 & 2,7 & 70,1 & 60,0 \\
\hline Mbo2 - niet groen & 2013 & 9,4 & 68,9 & 68,0 \\
\hline Mbo2 - niet groen & 2018 & 3,3 & 74,4 & 58,0 \\
\hline Mbo3 - donkergroen & 2008 & 4,6 & 50,9 & 56,8 \\
\hline Mbo3 - donkergroen & 2013 & 7,4 & 58,9 & 67,7 \\
\hline Mbo3 - donkergroen & 2018 & 3,5 & 68,9 & 58,7 \\
\hline Mb03 - lichtgroen & 2008 & 0,8 & 79,3 & 82,7 \\
\hline Mb03 - lichtgroen & 2013 & 3,8 & 68,9 & 89,7 \\
\hline Mbo3 - lichtgroen & 2018 & 2,0 & 70,8 & 73,4 \\
\hline Mbo3 - niet groen & 2008 & 1,9 & 74,1 & 77,2 \\
\hline Mbo3 - niet groen & 2013 & 7,0 & 67,0 & 77,0 \\
\hline Mbo3 - niet groen & 2018 & 2,3 & 76,3 & 71,7 \\
\hline Mb04 - donkergroen & 2008 & 1,3 & 78,5 & 61,3 \\
\hline Mb04 - donkergroen & 2013 & 6,4 & 70,6 & 65,6 \\
\hline Mb04 - donkergroen & 2018 & 1,3 & 73,6 & 61,6 \\
\hline Mb04 - lichtgroen & 2008 & 0,0 & 90,8 & 93,9 \\
\hline Mbo4 - lichtgroen & 2013 & 2,9 & 90,0 & 92,2 \\
\hline Mb04 - lichtgroen & 2018 & 2,6 & 90,8 & 78,8 \\
\hline Mbo4 - niet groen & 2008 & 1,8 & 85,2 & 76,2 \\
\hline Mbo4 - niet groen & 2013 & 7,2 & 79,0 & 75,6 \\
\hline Mb04 - niet groen & 2018 & 2,2 & 81,9 & 69,9 \\
\hline Hbo-bachelor - donkergroen & 2008 & 4,7 & 78,2 & 74,7 \\
\hline Hbo-bachelor - donkergroen & 2013 & 10,3 & 69,5 & 66,6 \\
\hline Hbo-bachelor - donkergroen & 2018 & 5,9 & 77,1 & 75,8 \\
\hline
\end{tabular}

9 https://roa.nl/schoolverlatersonderzoeken-school-leaver-surveys

10 https://www.vsnu.nl/nae.html 
Tabel 6 (vervolg)

\begin{tabular}{|l|r|r|r|r|}
\hline Hbo-bachelor - lichtgroen & 2008 & 7,9 & 88,3 & 84,3 \\
\hline Hbo-bachelor - lichtgroen & 2013 & 6,6 & 63,8 & 65,2 \\
\hline Hbo-bachelor - lichtgroen & 2018 & 5,3 & 82,3 & 75,8 \\
\hline Hbo-bachelor - niet groen & 2008 & 3,1 & 84,6 & 81,8 \\
\hline Hbo-bachelor - niet groen & 2013 & 7,9 & 72,5 & 73,7 \\
\hline Hbo-bachelor - niet groen & 2018 & 3,9 & 81,7 & 78,3 \\
\hline Wo-master - niet-groen & 2008 & 3.2 & 65.9 & 69.6 \\
\hline Wo-master - lichtgroen & 2008 & 0.0 & 82.9 & 89.7 \\
\hline Wo-master - donkergroen & 2008 & 3.9 & 68.9 & 80.1 \\
\hline
\end{tabular}

Bron: SIS en NAE, bewerking ROA

Noot: Informatie over WO-master gediplomeerden is alleen beschikbaar voor 2008.

Noot: De ongewogen $N$ varieerde in deze periode tussen de 30 en 13.373 per jaar.

Noot: Selectie op basis van voltijdsgediplomeerden.

Noot: Percentages berekend op basis van gewogen aantallen afgerond op tientallen.

De gevolgen van de economische crisis van 2007/2008 zijn in 2013 duidelijk terug te zien aan de werkloosheid. Deze was in 2008 en 2018 relatief laag, maar piekt in 2013 voor bijna alle niveaus en richtingen. Enige uitzondering hierop zijn de lichtgroene hbo-bachelor gediplomeerden, wiens werkloosheid terugloopt van bijna 8\% in 2008 naar 5.3\% in 2018. Analoog aan de algeheel hoge werkloosheid in 2013, zien we in 2013 over de hele linie een tijdelijke dip in het percentage afgestudeerden dat werkzaam is op eigen niveau en in eigen richting.

Een andere opvallende uitkomst is het aandeel lichtgroene mbo4-gediplomeerden dat aangeeft op eigen niveau werkzaam te zijn. Dit percentage (gemiddeld ruim 90\%) ligt beduidend hoger dan bij de meeste andere opleidingsrichtingen en niveaus.

Mbo2-gediplomeerden geven aan gemiddeld minder vaak in eigen richting te werken dan de andere niveaus. Vooral gediplomeerden van een donkergroene mbo2-opleiding melden gemiddeld in slechts $53 \%$ van de gevallen in hun eigen richting te werken.

Ook zien we dat gediplomeerden van donkergroene opleidingen op vrijwel alle niveaus (mbo4 uitgezonderd) in alle jaren een wat hogere werkloosheid rapporteren dan lichtgroen en niet-groen gediplomeerden op hetzelfde niveau, en dat op de meeste opleidingsniveaus geldt dat gediplomeerden van donkergroene opleidingen vaker aangeven buiten hun eigen richting en niveau te werken.

Tabel 7 gaat dieper in op de aansluiting tussen opleiding en arbeidsmarkt, zoals ervaren door gediplomeerden van voltijd opleidingen die werkzaam zijn. We rapporteren telkens het percentage dat een goede aansluiting ervaart. We maken gebruik van de meeste recente jaargangen die voldoende observaties bevatten. Voor het mbo en hbo 
zijn dit net als de voorgaande tabellen de jaren 2008, 2013 en 2018 van het SIS. Voor het wo de jaren 2006 en 2017 van de NAE.

\section{Tabel 7}

Subjectieve aansluiting op de arbeidsmarkt, \% werkzame gediplomeerden dat een goede aansluiting ervaart

\begin{tabular}{|l|l|r|r|r|r|r|}
\hline Niveau & Richting & 2006 & 2017 & 2008 & 2013 & 2018 \\
\hline Mbo 2 & Niet-groene opleiding & - & - & 79 & 80 & 80 \\
\hline Mb0 2 & Donkergroene opleiding & - & - & 79 & 78 & 77 \\
\hline Mb0 2 & Lichtgroene opleiding & - & - & 87 & 81 & 81 \\
\hline Mb0 3 & Niet-groene opleiding & - & - & 82 & 80 & 81 \\
\hline Mb03 & Donkergroene opleiding & - & - & 78 & 79 & 73 \\
\hline Mbo 3 & Lichtgroene opleiding & - & - & 90 & 84 & 85 \\
\hline Mbo 4 & Niet-groene opleiding & - & - & 77 & 74 & 74 \\
\hline Mbo 4 & Donkergroene opleiding & - & - & 77 & 66 & 69 \\
\hline Mbo 4 & Lichtgroene opleiding & - & - & 82 & 87 & 84 \\
\hline Hbo Bachelor & Niet-groene opleiding & - & - & 77 & 72 & 76 \\
\hline Hbo Bachelor & Donkergroene opleiding & - & - & 72 & 66 & 77 \\
\hline Hbo Bachelor & Lichtgroene opleiding & - & - & 82 & 55 & 73 \\
\hline Wo Master & Niet-groene opleiding & 77 & 85 & - & - & - \\
\hline Wo Master & Donkergroene opleiding & 80 & 85 & - & - & - \\
\hline Wo Master & Lichtgroene opleiding & 78 & 90 & - & - & - \\
\hline
\end{tabular}

Bron: SIS en NAE, bewerking ROA

Noot: De ongewogen $\mathrm{N}$ varieerde in deze periode tussen de 30 en 12.837 per jaar.

Noot: Percentages berekend op basis van gewogen aantallen afgerond op tientallen.

Noot: selectie op basis van voltijdsgediplomeerden.

De subjectieve aansluiting in 2013 zoals weergegeven in tabel 7 is voor de meeste niveaus en richtingen wat lager dan die in 2008, wat wederom een logisch gevolg van de crisis lijkt. Gediplomeerden van lichtgroene opleidingen geven voor de meeste niveaus en jaren vaker aan een goede aansluiting te ervaren dan gediplomeerden van donkergroene en niet-groene opleidingen. Gediplomeerden van donkergroene mboopleidingen ervaren minder vaak een goede aansluiting met de arbeidsmarkt. Dit is in lijn met de hogere werkloosheidspercentages en het minder vaak werkzaam zijn in de eigen richting of op eigen niveau, zoals tabel 6 toonde.

\section{In hoeverre komen groen-gediplomeerden in groene-beroepen terecht?}

Figuren 10 en 11 tonen over tijd in hoeverre gediplomeerden van respectievelijk mbo en ho opleidingen terecht komen in een beroep in hun studierichting. Van de donkergroene mbo-gediplomeerden komt slechts de helft in een beroep terecht dat we in het kader van dit project als donkergroen (of lichtgroen) hebben geclassificeerd. Dit fluctueert weinig over tijd. De andere helft komt dus terecht in een niet-groen beroep. 
Vanuit een lichtgroene mbo-opleiding komt gemiddeld ruim $70 \%$ terecht in een lichtgroen beroep. Hier komen gediplomeerden dus minder vaak in een ander beroepsdomein terecht. Dit komt overeen met de doorgaans betere subjectieve aansluiting zoals weergegeven in tabellen 6 en 7.

\section{Figuur 10}

Beroepsrichting waarin mbo-gediplomeerden terecht komen, 2013-2018.

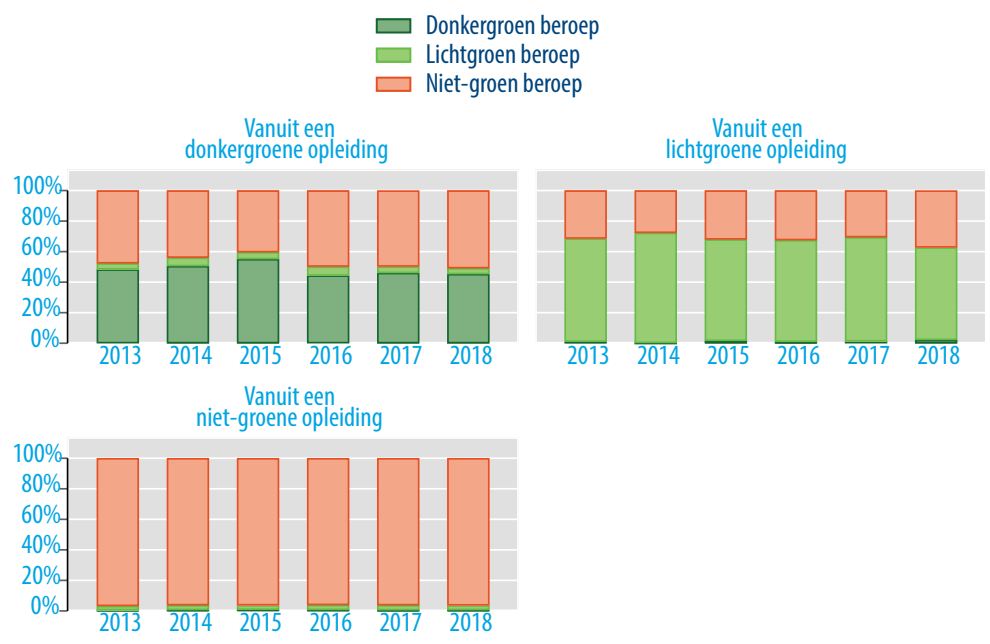

Bron: SIS en NAE, bewerking ROA

Gediplomeerden van zowel donkergroene als lichtgroene hbo-bachelor opleidingen komen doorgaans in ongeveer $45 \%$ van de gevallen terecht in een licht- of donkergroen beroep. Dat is minder vaak een aansluiting naar een groen beroep dan we bij mbo groen gediplomeerden zagen. Hbo-bachelors zijn vaak breder opgeleid (voor een vakgebied en niet direct voor een beroepsrichting) waardoor ze flexibeler inzetbaar zijn op de arbeidsmarkt dan mbo'ers. 


\section{Figuur 11}

Beroepsrichting waarin hbo-bachelor gediplomeerden terecht komen, 2013-2018.

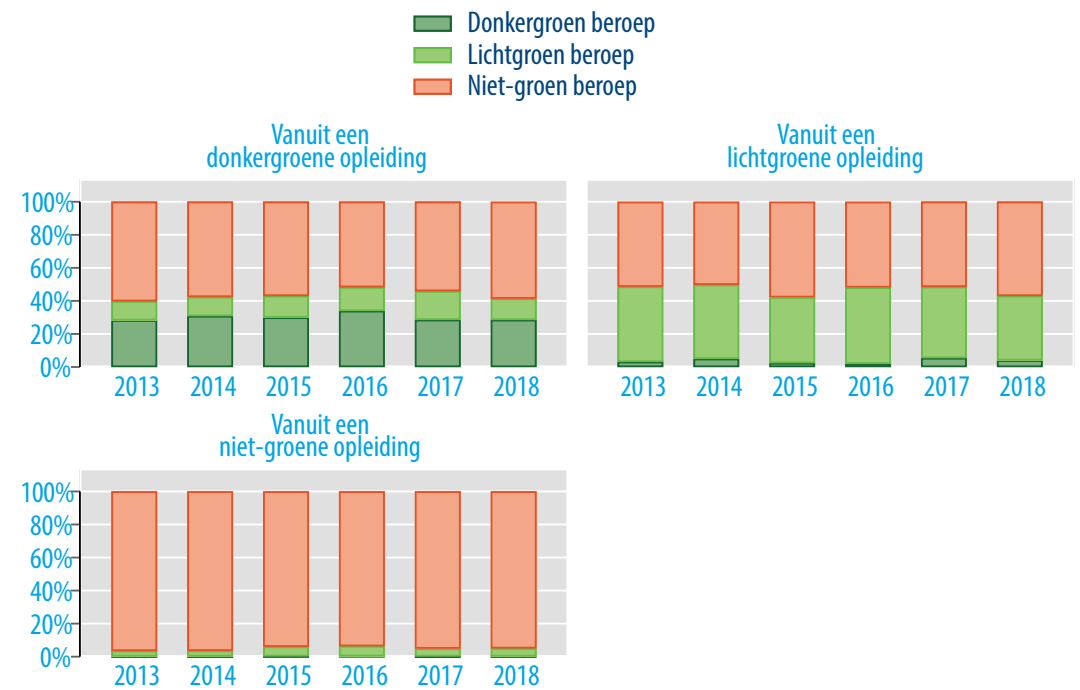

Bron: SIS en NAE, bewerking ROA

Tabel 8 biedt een detailinzicht in welke achtergrondkenmerken in de loop der jaren een grotere kans geven om vanuit een groene opleiding in een groen beroep terecht te komen. We pakken alle licht- en donkergroene opleidingen in deze tabel samen. We zien hierin bijvoorbeeld dat gediplomeerden van groene mbo-opleidingen die later ook in een licht- of donkergroen beroep werken gemiddeld jonger, vaker man en fulltime werkend zijn.

In het hbo is deze trend minder duidelijk te zien, de leeftijden van de gediplomeerden in een groen beroep verschillen weinig van die in een niet-groen beroep, evenals het percentage vrouw. Wel is het opvallend dat het aandeel deeltijdwerkers groter is bij hbo-gediplomeerden in een groen beroep dan bij een niet-groen beroep. Dit is uitzonderlijk vergeleken met de meeste andere opleidingsniveaus, waar het aandeel deeltijdwerkers in groene beroepen doorgaans kleiner is dan bij niet-groene beroepen. De tabel toont ook dat voor bijna alle mbo- en hbo-opleidingen, ongeacht niveau of richting, het aandeel gediplomeerden dat in een deeltijdbaan terecht kwam in 2013 hoger is dan in 2008 en 2018. Dit bevestigt de eerdere genoemde negatieve gevolgen van de financieel-economische crisis, waardoor veel gediplomeerden in de tussenliggende periode met een suboptimale baan genoegen moesten nemen, qua deeltijdfactor, richting en niveau. 


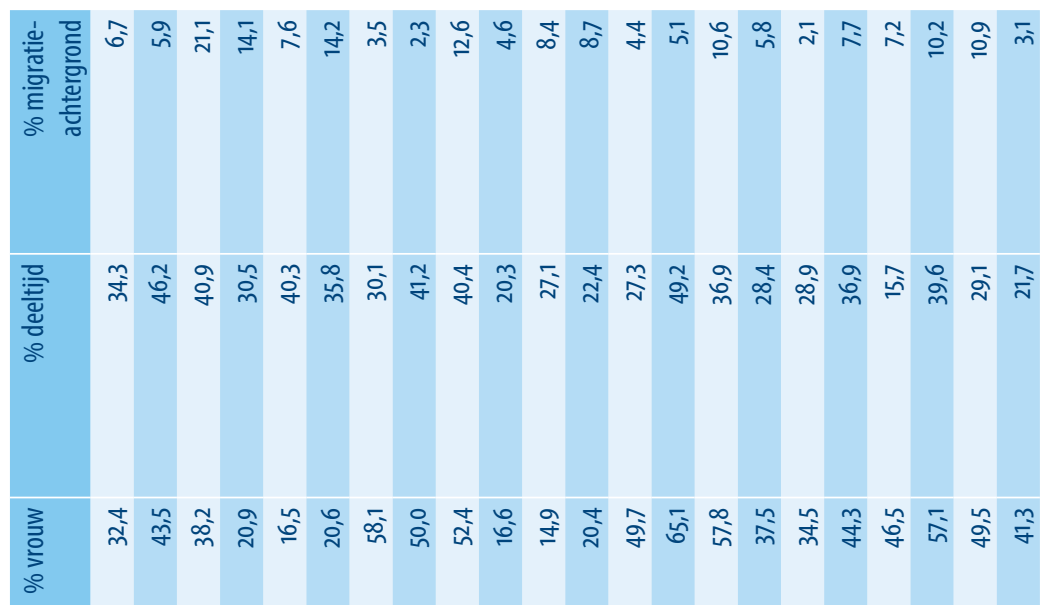

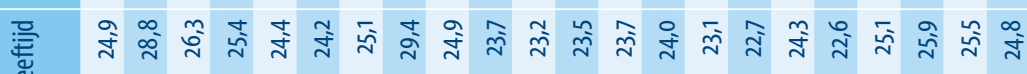

음

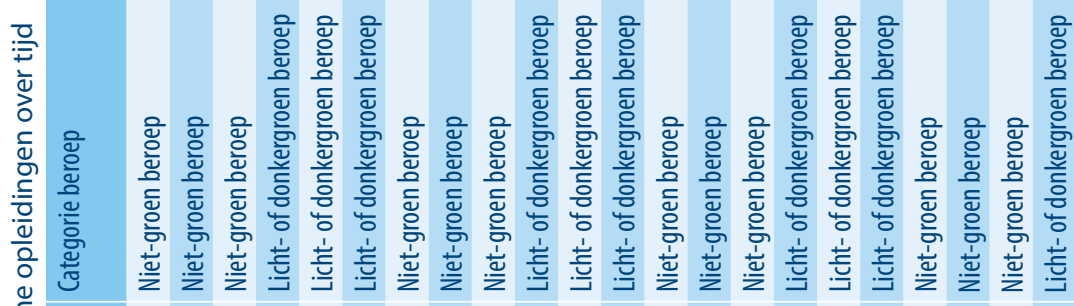

ᄃ

용

흄

을

으

$\frac{\sqrt{0}}{2}$

$\frac{c}{\frac{1}{0}}$

밀

है

응

O 竞

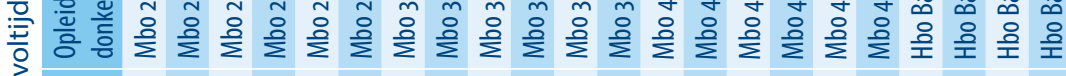

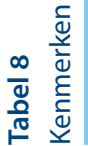

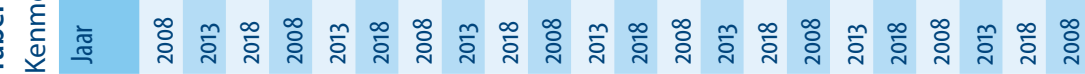




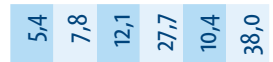

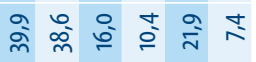

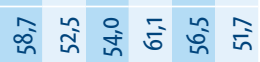

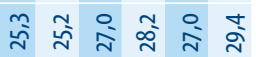

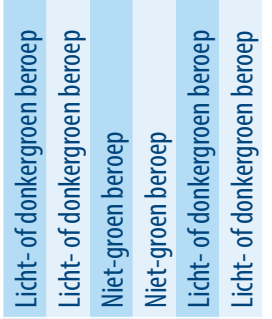

京.

ฆั 응

ริ ธิ

व

น

รे

둥

๙

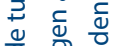

은 월

ฮ ठ

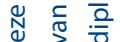

듬

రิ

웡 응

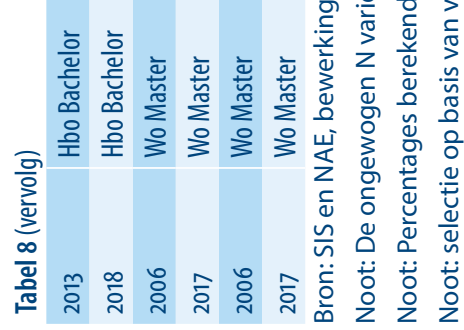


Hangt het uurloon van groen gediplomeerden af van of ze in een groep beroep terecht

\section{komen?}

Tot slot tonen wij in dit hoofdstuk aan de hand van regressieanalyses in welke mate er een relatie is tussen het loon van schoolverlaters op ieder niveau en het werken in een licht- of donkergroen beroep.

\section{Tabel 9}

OLS-regressie voor het uurloon, recent gediplomeerden groenopgeleiden (lichtgroen en donkergroen).

\begin{tabular}{|l|c|c|c|c|c|}
\hline & \multicolumn{5}{|c|}{ Uurloon groen gediplomeerden in groen beroep t.o.v. niet-groen } \\
& Mbo 2 & Mbo 3 & Mbo 4 & Hbo & Wo \\
\hline Variabelen & beroep, per niveau \\
\hline Donkergroen beroep & $-0,081^{* * *}$ & $0,020^{* *}$ & $-0,005$ & $-0,104^{* * *}$ & $-0,073^{* * *}$ \\
\hline Lichtgroen beroep & $(0,008)$ & $(0,009)$ & $(0,009)$ & $(0,011)$ & $(0,011)$ \\
\hline & $-0.048^{* * *}$ & $0,044^{* * *}$ & $0,096^{* * *}$ & $0,088^{* * *}$ & $0,053^{* * *}$ \\
\hline Gewogen N & $(0.008)$ & $(0,008)$ & $(0,014)$ & $(0,012)$ & $(0,014)$ \\
\hline R-squared & 8.110 & 7.300 & 5.920 & 4.050 & 3.360 \\
\hline Ongewogen N & 0,411 & 0,419 & 0,196 & 0,133 & 0,082 \\
\hline
\end{tabular}

Bron: SIS en NAE, bewerking ROA

Noot: gewogen aantallen afgerond op tientallen.

Noot: selectie op basis van voltijdsgediplomeerden.

Noot: Leeftijd, geslacht, herkomst, jaar, en dummy parttime werk als controlevariabelen, Niet-groen is de referentiecategorie.

Tabel 9 toont een aantal dingen. Bijvoorbeeld dat gediplomeerden van groene mbo2opleidingen aanzienlijk minder verdienen in een groen beroep dan in een niet-groen beroep. Tevens dat de uurlonen van alle groen gediplomeerden die in een donkergroen beroep werkzaam zijn, lager zijn dan wanneer ze in een niet-groen beroep werkzaam zijn, met als enige uitzondering groen gediplomeerden van mboz-niveau. In een lichtgroen beroep daarentegen, wordt door groen afgestudeerden over het algemeen meer verdiend dan in een niet-groen beroep (mbo2 uitgezonderd).

\subsection{Kort en krachtig hoofdstuk 3}

- Stijgend aantal deelnemers in donkergroen hoger onderwijs, maar daling in aantal deelnemers in donkergroen middelbaar onderwijs. Dit komt overeen met de algemene trend in het onderwijs en is dus niet sectorspecifiek voor de groene opleidingen.

- Aantal deelnemers aan lichtgroene opleidingen is na jaren van toename vrij recent afgenomen in zowel het mbo als ho. 
- Gediplomeerden van donkergroene mbo-opleidingen studeren minder vaak door dan niet-groen gediplomeerden, terwijl gediplomeerden van lichtgroene mboopleidingen juist vaker doorstuderen.

- In het hoger onderwijs studeren gediplomeerden van een donkergroene en lichtgroene opleiding vaker door dan gediplomeerden van een niet-groene opleiding.

- Donkergroene ho-gediplomeerden studeren vaker door binnen hun eigen richting, terwijl de doorstroomrichting van lichtgroen gediplomeerden is meer versnipperd.

- Donkergroene (vooral mbo) gediplomeerden zijn na diplomering vaker aan de slag als zelfstandige.

- Percentage mbo-gediplomeerden dat werkt stijgt in de jaren na diplomering. Voor ho-gediplomeerden blijft dit redelijk stabiel.

- Lichtgroene gediplomeerden komen in ongeveer $70 \%$ van de gevallen terecht in een lichtgroen beroep. Zij ervaren ook een relatief hoge mate van subjectieve aansluiting op de arbeidsmarkt.

- Van de donkergroen gediplomeerden komt $45-50 \%$ in een groen beroep terecht. Desondanks ervaren ook zij een relatief hoge mate van subjectieve aansluiting met de arbeidsmarkt, wat een interessante vraag voor nader onderzoek opwerpt.

- De lonen 5 jaar na afstuderen liggen doorgaans het hoogst voor niet-groen gediplomeerden, achtereenvolgens gevolgd door lichtgroen- en donkergroen gediplomeerden.

- Gediplomeerden van groene opleidingen verdienen vaak een hoger uurloon wanneer ze in een niet-groen beroep terecht komen dan wanneer ze in een donkergroen beroep gaan werken. Daarentegen kunnen ze doorgaans in een lichtgroen beroep een hoger uurloon verdienen dan in een niet-groen beroep.

- Donkergroene beroepen lijken dus in termen van uurloon achter te blijven op lichtgroene en niet-groene beroepen. 


\section{Analyses van de taken en ontwikkelinspanningen van werkenden in groene beroepen}

Op basis van data van de Leven Lang Leren enquête ${ }^{12}$ en de Nederlandse Skills Survey ${ }^{13}$ kunnen we inzichten krijgen in de taken van werkenden in groene beroepen en in hun inspanning op het gebied van formeel- en informeel leren - en kunnen we dit vergelijken met werkenden in niet-groene beroepen (de Grip et al, 2018; van den Berg et al, 2018). ${ }^{14}$ Specifiek kijken we naar een aantal indicatoren zoals het aantal gevolgde trainingen, het percentage informeel leren en de mate van complexiteit en multitasking die beroepen vereisen.

Figuur 12 toont dat werkenden in donkergroene beroepen een significant lager aantal gevolgde trainingen rapporteert over de twee jaar voorafgaand aan het moment van bevraging, dan werkenden in lichtgroene en niet-groene beroepen.

12 https://roa.nl/roa-life-long-learning

13 https://roa.nl/research/research-projects/tasks-and-skills-workplace

14 Het veldwerk van NSS en LLL is uitgezet onder het LISS panel, wat een representatieve steekproef van huishoudens is uit het bevolkingsregister van het CBS. Zie voor details: https://www.lissdata.nl/about-panel 


\section{Figuur 12}

Aantal gevolgde trainingen naar beroep, (2017)

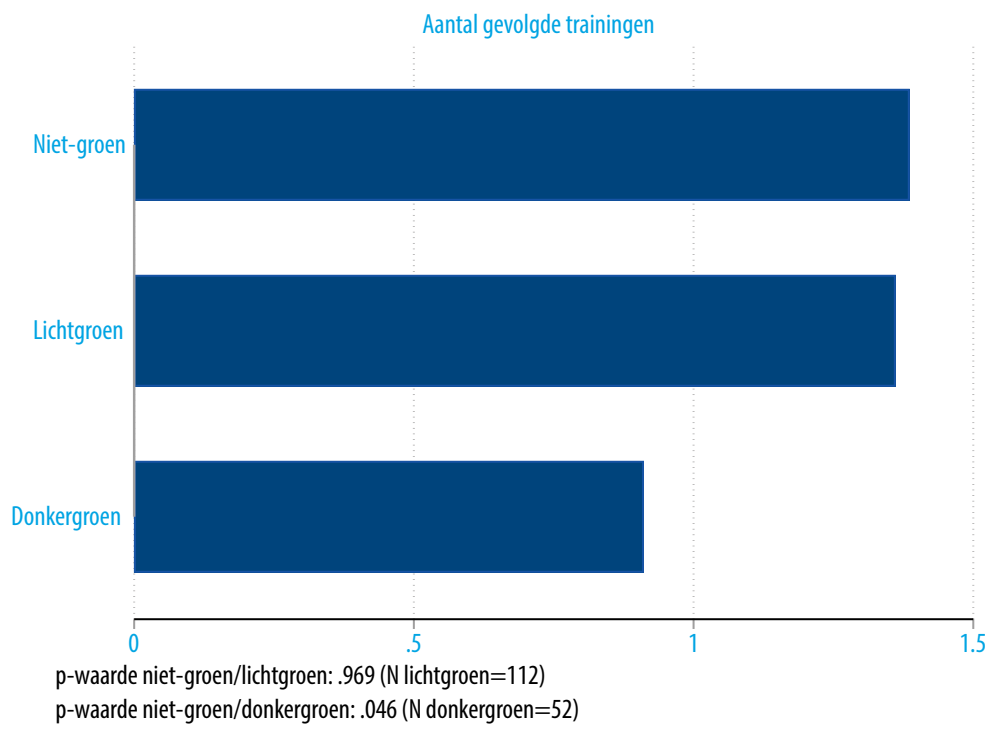

Bron: LLL 2017, bewerking ROA

Figuur 13 toont dat ook op het gebied van informeel leren, werkenden in donkergroene beroepen lager antwoorden dan werkenden in een lichtgroene of niet-groene beroepen, hoewel het verschil in dit geval niet significant is. 


\section{Figuur 13}

Percentage informeel leren naar beroep, (2017)

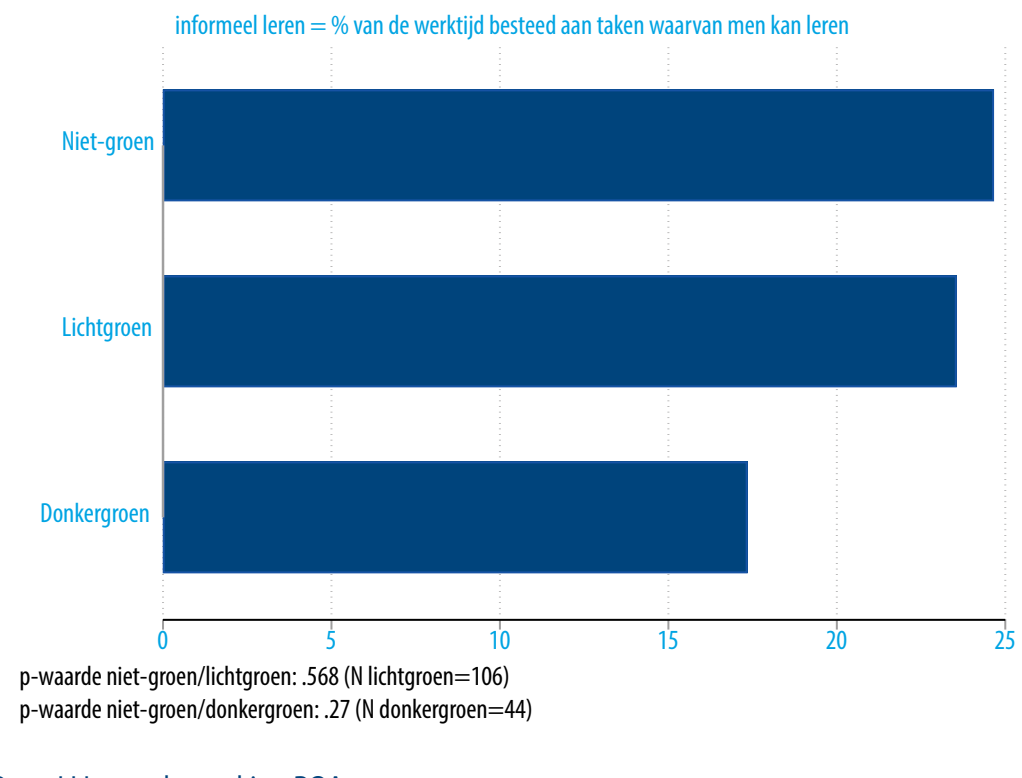

Bron: LLL 2017, bewerking ROA

Figuur 14 toont dat werkenden in donkergroen beroepen significant minder complexiteit in hun beroep ervaren dan mensen in niet-groen beroepen. Daarentegen ervaren werkenden in lichtgroene beroepen juist significant meer complexiteit in hun beroep dan werkenden in niet-groene beroepen. Dit construct complexiteit wordt in de NSS gemeten door 33 items. Deze items meten in hoeverre bepaalde taken belangrijk zijn in het werk van de respondent (op schaal van 1 tot 5). Een voorbeeld van zo'n item is de taak: controleren om te voorkomen dat er fouten worden gemaakt of problemen ontstaan. 


\section{Figuur 14}

Complexiteit van beroep, (2017)

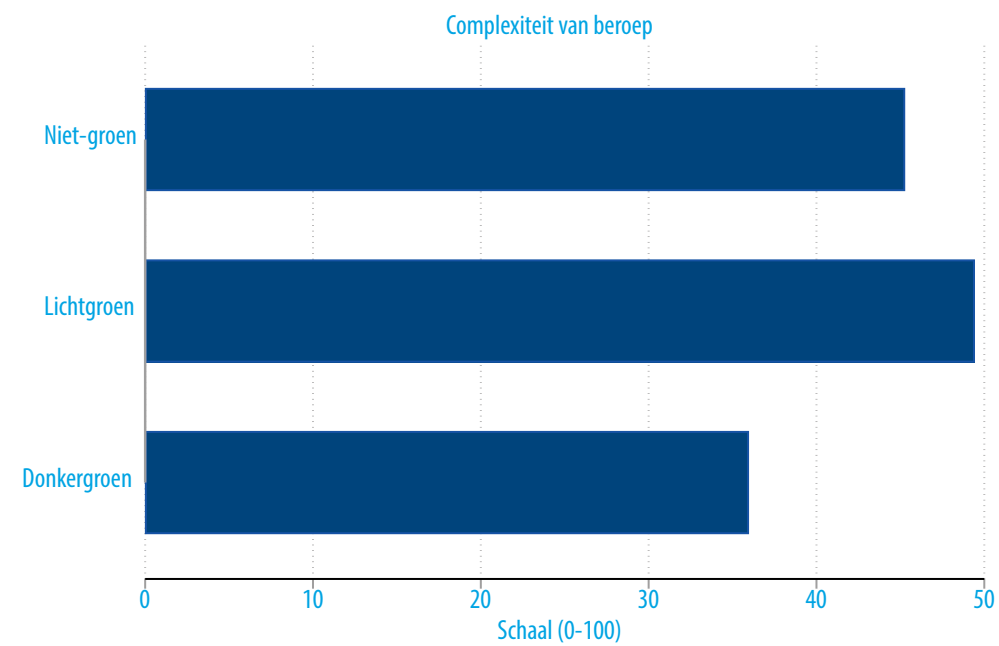

p-waarde niet-groen/lichtgroen: .023 (N lichtgroen=91)

p-waarde niet-groen/donkergroen: .001 ( $N$ donkergroen $=37$ )

Bron: NSS 2017, bewerking ROA

Tot slot toont figuur 15 dat werkenden in donkergroene beroepen significant minder aan multitasking hoeven doen in hun werk dan werkenden in niet-groene beroepen. Daarentegen multitasken werkenden in lichtgroene beroepen juist significant meer dan werkenden in niet-groene beroepen. Dit construct multitasking wordt gemeten op basis van het aantal verschillende taken dat volgens respondenten van belang is voor hun werk. 


\section{Figuur 15}

Multitasking naar beroep, (2017)

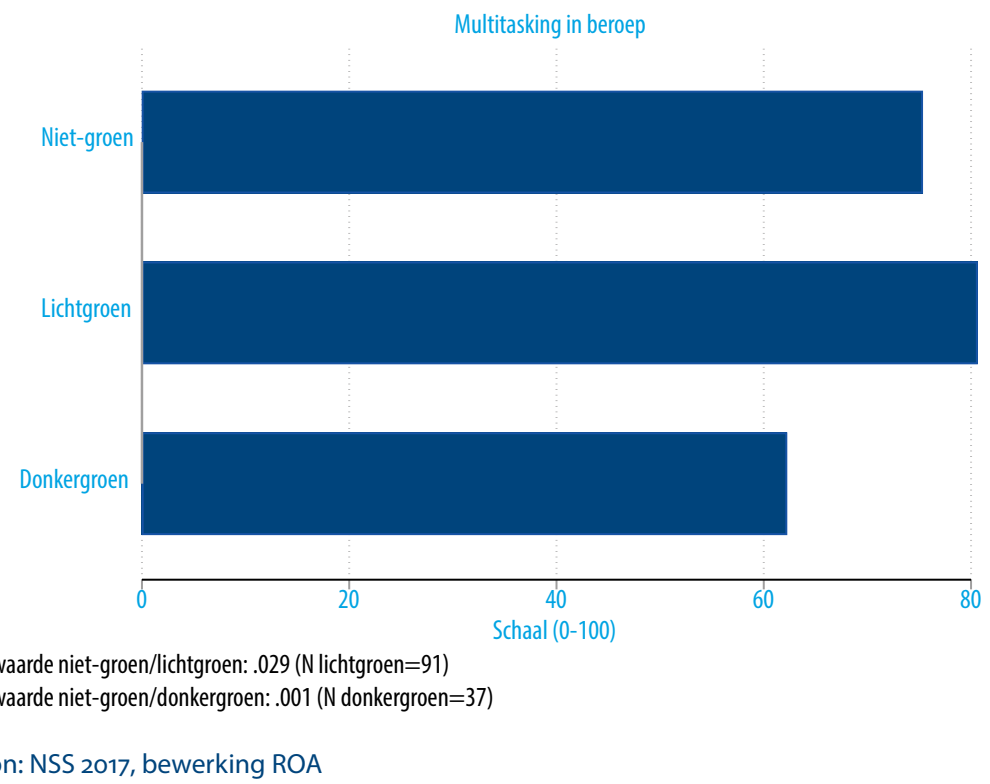

\subsection{Kort en krachtig hoofdstuk 4}

- Personen in donkergroene beroepen geven aan relatief minder trainingen te volgen en minder tijd te besteden aan informeel leren dan personen in lichtgroene en nietgroene beroepen.

- Lichtgroene beroepen worden ervaren als meer complex met een hogere mate van multitasken dan donkergroene niet-groene beroepen. 



\section{Verdiepende analyse van de beroepen- en sectorale mobiliteit in de groene sector}

In dit hoofdstuk kijken we naar de mobiliteit van werkenden van en naar de groene sector over de periode 2005-2018. Eerst kijken we op basis van survey-data uit de EBB (Enquête Beroepsbevolking) welke beroepsgroepen in welke sectoren werkzaam zijn. Vervolgens kijken we op basis van CBS microdata naar sectorale mobiliteit van individuen van en naar groene en niet-groene sectoren.

\subsection{In hoeverre hebben groene beroepen een sterke binding met groene sectoren?}

In de EBB worden mensen gevraagd in welke beroepsgroep ze werkzaam zijn en in welke sector. Net zoals in eerdere hoofdstukken, hebben we dit gekoppeld aan de ROA/ Groenpact classificatie van groene beroepen en sectoren. Deze informatie kunnen we visualiseren om een beeld te schetsen van de verdeling beroepen binnen de, al dan niet groene, sectoren. Dit is gevisualiseerd in figuur 16.

Meest opvallend aan figuur 16 is dat de donkergroene bedrijfssector over tijd aflopend gevuld is met (werkenden in) groene beroepen. Er is een duidelijke daling te zien van licht- en donkergroene beroepen in de donkergroene sector. Het percentage werkenden in niet-groene beroepen neemt dus toe in de donkergroene sector. Veel bedrijven in de donkergroene sector zullen bijvoorbeeld mensen in dienst hebben voor administratie, personeelszaken of logistiek. Dit lijkt erop te wijzen dat het aandeel 'niet-groene taken' in donkergroene bedrijven is toegenomen, met als uitkomst steeds meer werkenden met niet-groene beroepen in deze donkergroene bedrijven. Omgekeerd kunnen mensen ook werkzaam zijn als hovenier in dienst van een hotel of gemeente, wat in beide gevallen een donkergroen beroep zou zijn in een niet-groene bedrijfssector. Dit aandeel is echter maar zeer klein en fluctueert nauwelijks.

De lichtgroene bedrijfssector verschilt maar weinig met de niet-groene bedrijfssector. Beide sectoren kennen een redelijke stabiele samenstelling van beroepen, en bestaan voor het grootste gedeelte uit niet-groene beroepen. Het aandeel groene beroepen in de lichtgroene bedrijfssector is ongeveer $10 \%$. In de lichtgroene sector zit bijvoorbeeld vervaardiging van textiel en hout, maar ook banken en winkels voor voedsel. Dit zijn erg uiteenlopende bedrijfssectoren die dus ook mensen in dienst hebben met uiteenlopende beroepen. 
Figuur 16

Aandeel beroepen werkzaam in Groenpact-sectoren 2006-2018.

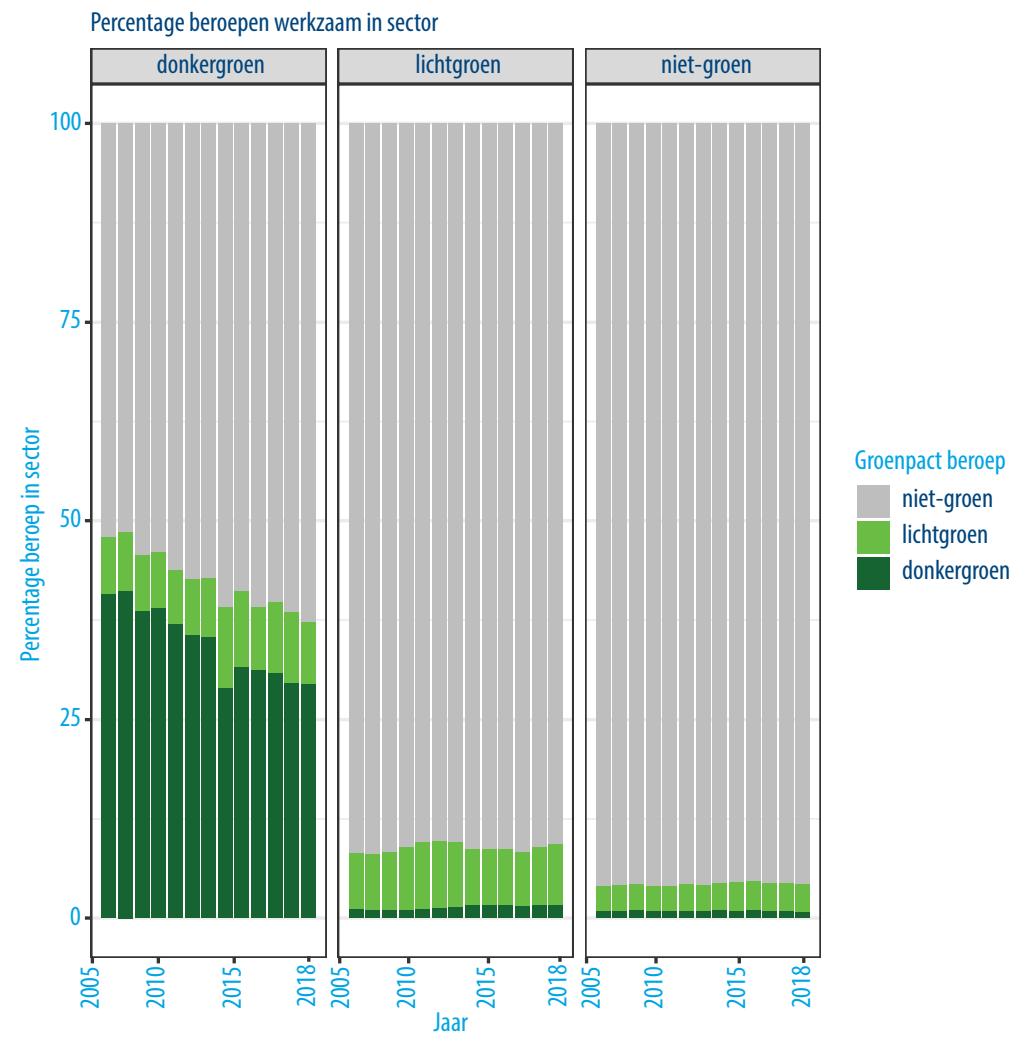

Bron: EBB, bewerking ROA

\subsection{Mobiliteit van en naar de groene sector}

Op basis van CBS microdata, met informatie over de positie van individuen op de arbeidsmarkt, kunnen we voor elk jaar kijken in welke bedrijfssectoren de beroepsbevolking werkzaam is. Voor de onderstaande analyses hebben we elk jaar op peildatum 31 december de positie op de arbeidsmarkt in kaart gebracht, inclusief de sector waarin men werkt. Omdat de meeste mensen niet zo heel frequent van baan of sector wisselen hebben we alle mobiliteit over de periode 2008-2018 gemiddeld. Figuur 17 toont de gemiddelde instroom naar sectoren die aan de rechterkant vermeld staan. De herkomst van de instroom staat aan de linkerkant. We onderscheiden de voor dit project nieuw geclassificeerde sectoren donkergroen, lichtgroen en niet-groen. De vierde mogelijkheid is dat mensen zich niet meer bevinden in de sociaaleconomische categorieën van werknemer of zelfstandige (11 t/m 15). Dit zijn dan mensen die ofwel uitkeringen ontvangen, student zijn of helemaal niet meer staan ingeschreven in de Nederlandse 
registers (en dus mogelijk naar het buitenland zijn verhuisd). Deze mogelijkheid heet 'Niet SECM 11-15'.

\section{Figuur 17}

Gemiddelde sectorale instroom SECM 2008-2018.

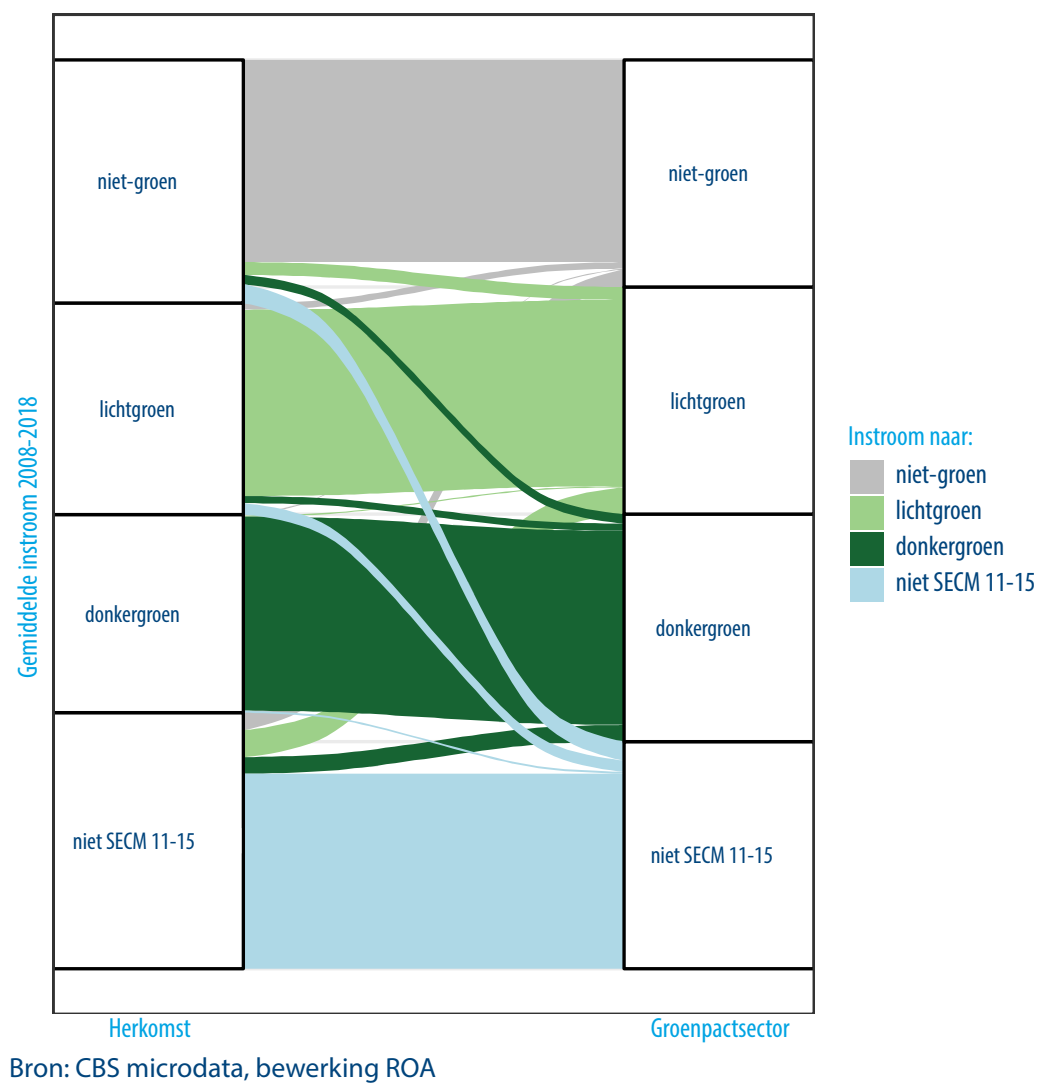

Figuur 17 toont dat er weinig sectorale mobiliteit is geweest tussen 2008 en 2018. De grootste stromen blijven binnen dezelfde bedrijfssector. Een van de meer opvallende ontwikkelingen is de relatief grote set stromen vanuit een niet-werkende positie (niet SECM 11-15) (terug) op de arbeidsmarkt, en dan vooral naar de lichtgroene bedrijfssector.

In figuur 18 wordt de gemiddelde sectorale uitstroom weergegeven. Links zien we dus er sector waar men uit stroomt en rechts de bestemming. Vanuit alle sectoren, zowel nietgroen als groen, stroomt ongeveer een gelijk deel uit de arbeidsmarkt (naar niet SECM). Daarnaast zien we vanuit de licht- en niet-groene bedrijfssector nauwelijks uitstroom naar de donkergroene bedrijfssector, maar andersom zijn er wel kleine aandelen die 
vanuit de donkergroene naar de overige bedrijfssectoren uitstromen. Omdat figuren 17 en 18 elkaars spiegelbeeld lijken te zijn, zijn er slechts minieme verschillen die de'netto stromen' vertegenwoordigen. Deze zijn daarom niet apart in beeld gebracht.

\section{Figuur 18}

Gemiddelde sectorale uitstroom 2008-2018.

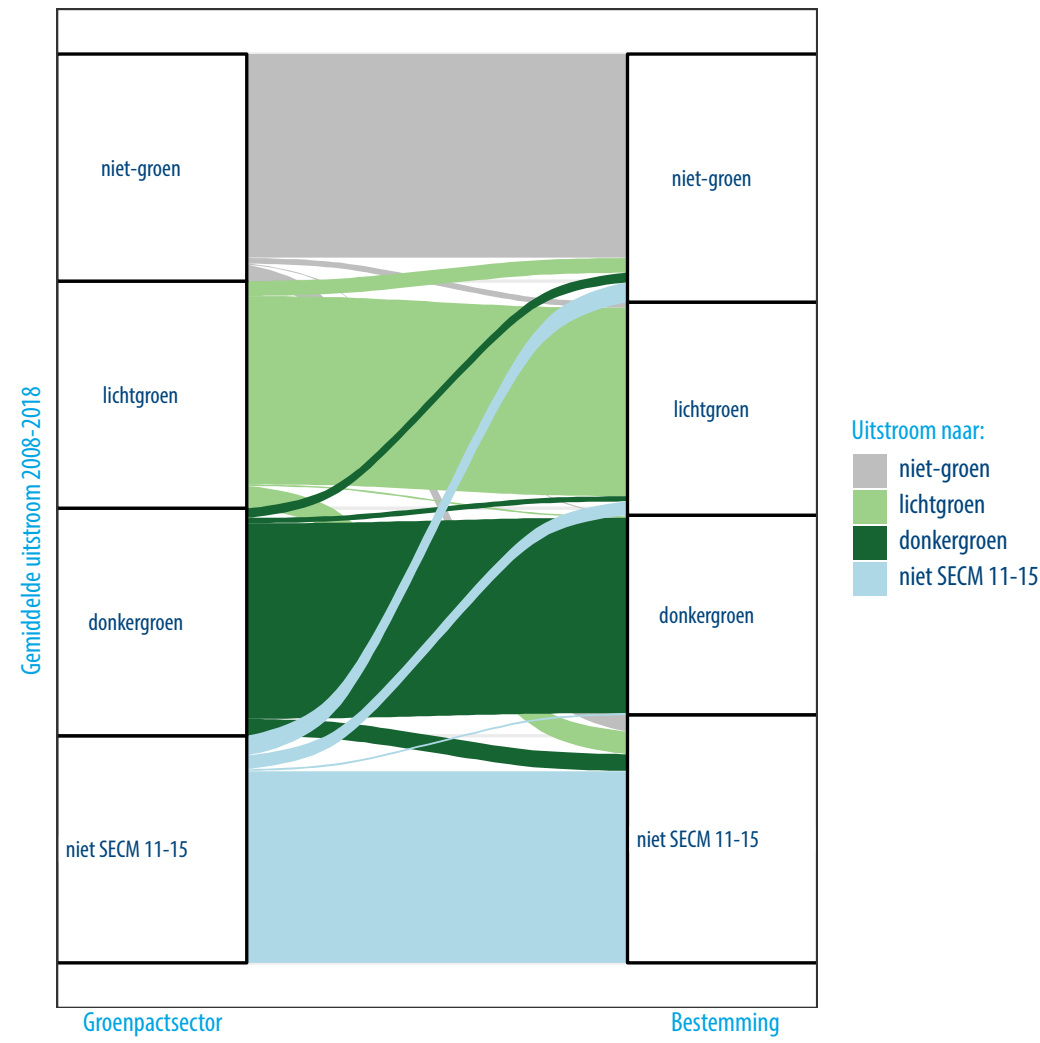

Bron: CBS microdata, bewerking ROA

\subsection{Kort en krachtig hoofdstuk 5}

- Er zijn steeds meer personen met niet-groene beroepen werkzaam in de donkergroene bedrijfssector.

- Het aandeel personen in groene beroepen in lichtgroene bedrijfssectoren is beperkt.

- Er is weinig sectorale mobiliteit van en naar de licht- en donkergroene sectoren. 


\section{Conclusie en doorkijk}

Dit rapport bevat de bevindingen van sectorspecifiek onderzoek op basis van bestaande data, naar de aansluiting tussen onderwijs en arbeidsmarkt in de groene sector. Dit onderzoek biedt daarmee ook een inzicht in wat er met de bestaande data infrastructuur kan worden onderzocht met betrekking tot de groene sector.

Het beeld dat uit dit onderzoek ontstaat is dat de groene sector per saldo - afgaande op de ontwikkeling in leerlingenaantallen - tot pakweg 2016/2017 op een duidelijk toenemende interesse van jonge mensen kon rekenen. Hoewel het aantal leerlingen in donkergroene opleidingen in het hoger onderwijs nog altijd toeneemt, dalen inmiddels echter de leerlingenaantallen die voor een groene mbo of lichtgroene ho opleiding kiezen. Deze ontwikkelingen in leerlingenaantallen volgen grotendeels de algemene trends in het gehele onderwijs.

Uit dit onderzoek kunnen we concluderen dat de (donker)groene sector - zoals voor dit onderzoek gedefinieerd - op een aantal belangrijke arbeidsmarktindicatoren een relatief lager concurrerend vermogen lijkt te hebben dan de niet-groene sector.

Ten eerste kennen de lonen van afgestudeerden van groene opleidingen doorgaans een minder gunstig verloop dan de lonen van afgestudeerden van niet-groene opleidingen. Vijf jaar na afstuderen liggen de lonen doorgaans het hoogst voor niet-groen gediplomeerden, achtereenvolgens gevolgd door lichtgroen- en donkergroen gediplomeerden.

Ten tweede zien we dat gediplomeerden van groene opleidingen vaak een hoger uurloon verdienen wanneer ze in een niet-groen beroep terecht komen dan wanneer ze in een donkergroen beroep gaan werken. Samen suggereert dit dat donkergroene beroepen in termen van uurloon achter lijken te blijven op lichtgroene en niet-groene beroepen. Een belangrijke kanttekening is dat deze looninformatie gebaseerd is op werkenden in loondienst - en dat juist gediplomeerden van donkergroene opleidingen het vaakst als zelfstandige aan de slag gaan.

Ten derde volgen werkenden in donkergroene beroepen relatief minder trainingen en besteden ze minder tijd aan informeel leren dan werkenden in lichtgroene en nietgroene beroepen. Daarbij worden donkergroene beroepen als het minst complex ervaren en vereisen ze het minste aan multitasking. Het is bekend dat beroepen met een lagere complexiteit een historisch groter risico lopen om geautomatiseerd te worden (bijv. Feng \& Graetz, 2020). Het strekte niet tot de reikwijdte van dit onderzoek om een eventueel causaal verband te onderzoeken tussen de ervaren lagere complexiteit en 
multitasking met de kleinere inspanningen op het gebied van leven lang ontwikkelen in donkergroene beroepen.

Ten vierde zien we dat van de donkergroen gediplomeerden maar $45-50 \%$ in een groen beroep terecht komt, maar dat desondanks tussen de $69-85 \%$ (afhankelijk van opleidingsniveau) van donkergroen gediplomeerden een goede subjectieve aansluiting op de arbeidsmarkt ervaart - wat samen een interessante vraag voor verder onderzoek opwerpt. Van de lichtgroen gediplomeerden komt ongeveer $70 \%$ terecht in een lichtgroen beroep en zij ervaren ook een relatief hoge mate van subjectieve aansluiting op de arbeidsmarkt. Aangezien er weinig mobiliteit is tussen donkergroene, lichtgroene en niet-groene sectoren als men eenmaal aan het werk is, lijkt het moment van uitstroom naar de arbeidsmarkt een van de voornaamste momenten die de retentie van mensen beïnvloedt, samen met het moment van doorstromen binnen het onderwijs. Hoewel de retentie van met name donkergroen gediplomeerden op het eerste oog dus niet bijzonder hoog lijkt, is de keerzijde hiervan dat, vanuit perspectief van het onderwijscurriculum bekeken, (donker)groen gediplomeerden er over het algemeen in slagen om ook in niet-groene beroepen aan de slag te gaan.

In hoeverre verwachtingen van leerlingen en gediplomeerden over hun latere loon of ontwikkelmogelijkheden bepalend zijn voor de keuze om al dan niet in een groene richting door te studeren of te gaan werken is in dit onderzoek niet causaal onderzocht. Wat een dergelijke analyse nog zou bemoeilijken is het feit dat er in de donkergroene sector een steeds kleinere rol lijkt weggelegd voor mensen met een groen beroep. Het aandeel niet-groene beroepen in de donkergroene sector neemt namelijk al jaren toe, ten koste van het aandeel groene beroepen. Wellicht is het niet de verwachting omtrent later loon of ontwikkelmogelijkheden in de sector, maar de wetenschap dat er steeds minder groene beroepen zijn in de donkergroene sector, die mede bepalend is voor de keuzes van leerlingen en gediplomeerden. Als de trend is dat er relatief steeds minder plaats is voor groene beroepen in de (donker)groene sector en we zien dat maar 45-50\% van de donkergroen gediplomeerden in een groen beroep terecht, roept dat de interessante vraag op welke mechanismen dat veroorzaken.

Cruciale stap in dit project was dat wij in overleg met het Groenpact een nieuwe definitie van de groene sector hebben ontwikkeld. Dat deze maatwerk definitie van de groene sector er nu ligt was niet alleen een middel om tot de analyses in dit rapport te kunnen komen. Deze definitie is tevens een op zichzelf staand resultaat, waarvan het proces ook in detail een bijbehorende technische rapport beschreven staat (Methodiek ROA/ Groenpact-classificatie van de groene sector $\left.{ }^{15}\right)$.

15 I. Bijlsma, S. Dijksman, D. Fouarge, R. Gerards, S. Steens (2021). Methodiek ROA/Groenpact-classificatie van de groene sector. Maastricht: ROA-TR-2021/1. 
De classificaties kunnen nu gebruikt worden in toekomstig onderzoek in de sector, waarbij de focus bijvoorbeeld zou kunnen liggen op het periodiek herhalen van dit onderzoek voor de ontwikkeling van een monitor of het onderzoeken in hoeverre het mogelijk is binnen deze definitie verder in te zoomen op nader te specificeren subsectoren, regio's of (clusters) van beroepen of opleidingen. Ook zou een verdere verfijning kunnen ontstaan door onderscheid te maken tussen Bol en Bbl, hoewel dit onderscheid in de praktijk steeds meer fluide blijkt te zijn volgens Groenpact vertegenwoordigers. Tevens zouden de crebo codes op niveau 1 - die in dit onderzoek nog buiten beschouwing zijn gelaten omdat ze niet als startkwalificatie worden beschouwd - ook geclassificeerd kunnen worden tot donkergroen, lichtgroen of niet-groen. Ook zou vervolgonderzoek deze definitie kunnen gebruiken om te onderzoeken of er causale verbanden zijn tussen bijvoorbeeld de lonen in de sector en de retentie van leerlingen en gediplomeerden op momenten van doorstroom en uitstroom uit het onderwijs, of tussen de lagere complexiteit en multitasking met de kleinere inspanningen op het gebied van leven lang ontwikkelen in donkergroene beroepen. Tot slot leven er in de sector zelf ongetwijfeld talloze mogelijke onderzoeksvragen waarbij deze nieuwe definitie van de groene sector van waarde kan zijn. 



\section{Literatuur}

Bakens, J., Bijlsma, I., Dijksman, S., Fouarge, D., de Lombaerde, G. (2019). De arbeidsmarkt naar opleiding en beroep tot 2024. Maastricht: ROA-R-2019/7.

Beldman, A., Benninga, J., Benus, M., Bondt, N., ten Brummelhuis, A., van den Burg, S., van Dalfsen, P., Dijkxhoorn, Y., Groot, M., van Horne, P., Hoste, R., Jager, J., Janssens, B., Jellema, A., Kortstee, H., van der Meulen, H., Mol, A., Poot, E., Puister-Jansen, L., ... Berkhout, P., \& Bergevoet, R. (Eds.) (2020). De impact van de coronacrisis op het Nederlandse agrocomplex. (Wageningen Economic Research; No. 2020-088). Wageningen Economic Research. Geraadpleegd van: https://edepot.wur.nl/536350

Boerderij. (2018). Bedrijven zoeken naarstig naar agrarisch personeel. Geraadpleegd van: https://www.boerderij.nl/Home/Achtergrond/2018/11/Bedrijven-zoeken-naarstignaar-agrarisch-personeel-358272E/.

Centraal Planbureau. (2019). Centraal Economisch Plan 2019. Den Haag.

De Grip, A., Belfi, B., Fouarge, D., Künn, A., Peeters, T., \& Poulissen, D. (2018). Levenslang leren en competentieontwikkeling: Beleidsrapport. ROA. ROA Reports Nr. 008. Geraadpleegd van: https://doi.org/10.26481/umarep.2018008

De Jong, T., Tamsma, P., de Rooij, A., Kamps, M., \& Cremers, M. (2017). Duurzaam werken in de Agrarische en Groene Sector. Geraadpleegd van: https://www.stigas.nl/sites/ stigas.nl/files/wp-content/uploads/2018/o2/Rapportage-Duurzaam-Werken-in-deAgrarische-en-Groene-sector.pdf

De Wit, J., \& van den Beukel, L. (2019). Agrarische en groene sector Factsheet arbeidsmarkt. UWV Afdeling Arbeidsmarktinformatie en -advies. Amsterdam. Geraadpleegd van: https://www.uwv.nl/overuwv/Images/factsheet-agrarisch-groene\%20sector-2019. pdf

Feng, A., \& Graetz, G. (2020). Training Requirements, Automation, and Job Polarisation, The Economic Journal, Volume 130, Issue 631, Pages 2249-2271. Geraadpleegd van: https://doi.org/10.1093/ej/ueaao44

Fouarge, D. (2017). Veranderingen in de vraag naar vaardigheden. Tijdschrift voor het Economisch Onderwijs, 114 (6), 18-21.

Groenpact. (2020). De Groene Monitor 2020. Onderwijs en arbeidsmarkt in beeld. Geraadpleegd van: https://www.groenpact.nl/images/content/Groene\%20Monitor/ De\%20Groene\%20Monitor RGB\%20spread.pdf

Grotenhuis, M., van Hulle, R., \& de Kort, J. (2018). Arbeidsmarkt Colland 2018, Arbeidsmarktstructuur sector agrarisch en groen in beeld. Geraadpleegd van: https://www.collandarbeidsmarkt.nl/wp-content/uploads/2018/10/CollandArbeidsmarktonderzoek-2018.pdf 
Grotenhuis, M., \& van Hulle, R. (2020). Arbeidsmarkt Colland 2020, Arbeidsmarktstructuur sector agrarisch en groen in beeld. Geraadpleegd van: https://collandarbeidsmarkt. incijfers.nl/info/Arbeidsmarkt-Colland-2020-Onderzoeksdocumentatie.pdf

Motivaction. (2018). De groene sector aantrekkelijk voor jongeren? - Een segmentatieonderzoek naar drijfveren van jongeren om voor de groene sector te kiezen. Geraadpleegd van: https://edepot.wur.nl/453713

NRO. (2018). Evaluatie wet 'Doelmatige Leerwegen' mbo meting 2018. Nijmegen: KBA Nijmegen - ResearchNed. Geraadpleegd van: https://www.nro.nl/wp-content/ uploads/2018/10/Evaluatie-wet-Doelmatige-Leerwegen-mbo-meting2018.pdf

OECD. (2014), Education at a Glance 2014: OECD Indicators. Paris: OECD Publishing.

Panteia, De Beleidsonderzoekers. (2016). Arbeidsmarkt Colland 2016. Leiden. Geraadpleegd van: https://www.collandarbeidsmarkt.nl/arbeidsmarkt/wp-content/ uploads/2017/02/Panteia-Colland-Arbeidsmarktonderzoek-2016.pdf

SBB. (2019). Trendrapport Voedsel, Groen en Gastvrijheid 2019. Geraadpleegd van: https:// trendrapport.s-bb.nl/vgg/

UWV. (2019). UWV Arbeidsmarktprognose 2019-2020. Geraadpleegd van: https://www. uwv.nl/overuwv/Images/uwv-arbeidsmarktprognose-2019-2020.pdf

Van den Berg, E., Van Eldert, P., Fouarge, D., \& Ter Weel, B. (2018). Taken en vaardigheden op het werk. Bevindingen uit de eerste en tweede Nederlandse skills survey (NSS). ROA rapport. Maastricht: ROA Researchcentrum voor onderwijs en arbeidsmarkt.

Wielenga-van der Pijl, L., Van der Mooren, F., \& Pleijers, A. (2019). Kennispotentieel. In CBS. ICT, kennis en economie 2019. Geraagpleegd van: https://longreads.cbs.nl/ict-kennisen-economie-2019/

WUR. (2020). Inkomen land- en tuinbouw gedaald, wel grote verschillen tussen bedrijfstypen. Geraadpleegd van: https://www.agrimatie.nl/ThemaResultaat.aspx?subpubl $\mathrm{D}=2232 \&$ themal $\mathrm{D}=2272$ \&indicator $\mid \mathrm{D}=2046$ 


\section{Appendix}

\section{Appendix A}

Overzicht gebruikte bronnen bij analyses. Gekoppeld op kleinste aggregatieniveaus.

\begin{tabular}{|l|l|}
\hline Bron & Doel \\
\hline DUO & Onderwijsdata \\
\hline NSS & Complexiteit en multitasking in beroepen \\
\hline LLL & Gevolgde trainingen en leren in het beroep \\
\hline SIS/NAE & Aansluiting onderwijs-arbeidsmarkt, lonen, persoonlijke kenmerken \\
\hline SECMBUS & Kans op werk, registratie sociaal-economische categorie \\
\hline SPolisbus & Uurlonen \\
\hline EBB & Relatie mens-arbeidsmarkt, mobiliteit \\
\hline
\end{tabular}




\section{Appendix B}

Tabel overzicht doorstroom-percentages

\begin{tabular}{|c|c|}
\hline Opleidingsniveau & $\%$ doorstroom \\
\hline Mb02 - niet-groen & 39.7 \\
\hline Mb02 - lichtgroen & 48.5 \\
\hline Mbo2 - donkergroen & 29.2 \\
\hline Mb02 - totaal & 39.5 \\
\hline Mbo3 - niet-groen & 35.5 \\
\hline Mb03 - lichtgroen & 26.3 \\
\hline Mb03 - donkergroen & 21.3 \\
\hline Mbo3 - totaal & 34.2 \\
\hline Mb04 - niet-groen & 27.1 \\
\hline Mb04 - lichtgroen & 25.4 \\
\hline Mb04 - donkergroen & 28.3 \\
\hline Mb04 - totaal & 27.1 \\
\hline Mbo - niet-groen & 33.2 \\
\hline Mbo - lichtgroen & 38.1 \\
\hline Mbo - donkergroen & 26.2 \\
\hline Mbo - totaal & 33.0 \\
\hline Hbo-associate degree - niet-groen & 23.9 \\
\hline Hbo-associate degree - totaal & 23.1 \\
\hline Hbo-bachelor - niet-groen & 11.2 \\
\hline Hbo-bachelor - lichtgroen & 16.9 \\
\hline Hbo-bachelor - donkergroen & 17.1 \\
\hline Hbo-bachelor - totaal & 11.5 \\
\hline Wo-bachelor - niet-groen & 82.5 \\
\hline Wo-bachelor - lichtgroen & 89.2 \\
\hline Wo-bachelor - donkergroen & 87.4 \\
\hline Wo-bachelor - totaal & 82.8 \\
\hline Bachelor - niet-groen & 39.1 \\
\hline Bachelor - lichtgroen & 43.1 \\
\hline Bachelor - donkergroen & 49.3 \\
\hline Bachelor - totaal & 39.5 \\
\hline Hbo-master - niet-groen & 2.7 \\
\hline Hbo-master - totaal & 2.7 \\
\hline Wo-master - niet-groen & 4.3 \\
\hline Wo-master - lichtgroen & 3.9 \\
\hline Wo-master - donkergroen & 2.4 \\
\hline Wo-master - totaal & 4.2 \\
\hline Master - niet-groen & 4.3 \\
\hline Master - lichtgroen & 3.9 \\
\hline Master - donkergroen & 2.4 \\
\hline
\end{tabular}


Master - totaal 4.2

Ho - niet-groen 28.6

Ho - lichtgroen 29.6

Ho - donkergroen

Ho - totaal 28.8

Bron: CBS microdata, bewerking ROA 


\section{Appendix C}

Arbeidsmarktpositie van groen-gediplomeerden 1, 2 en 5 jaar na diplomering, (Cohort 20122013).

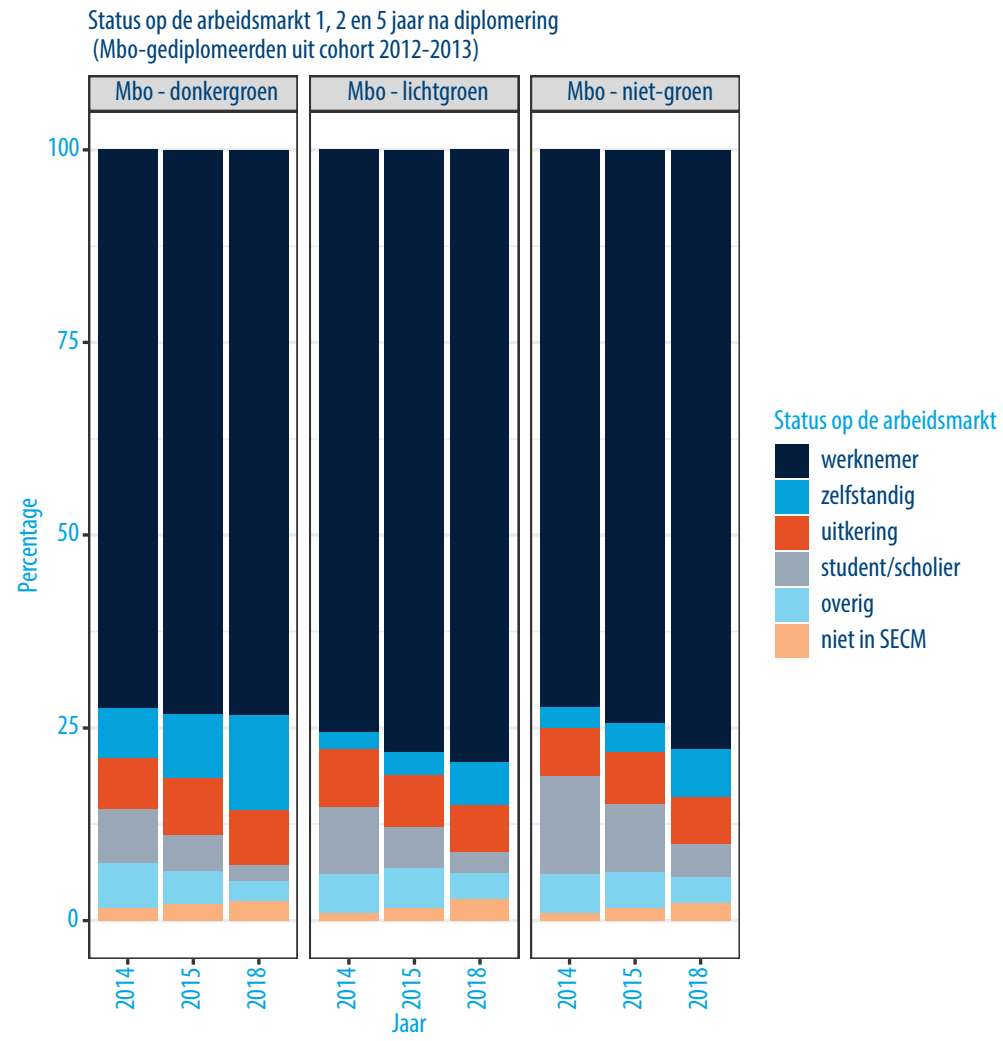

Bron: CBS microdata, bewerking ROA 


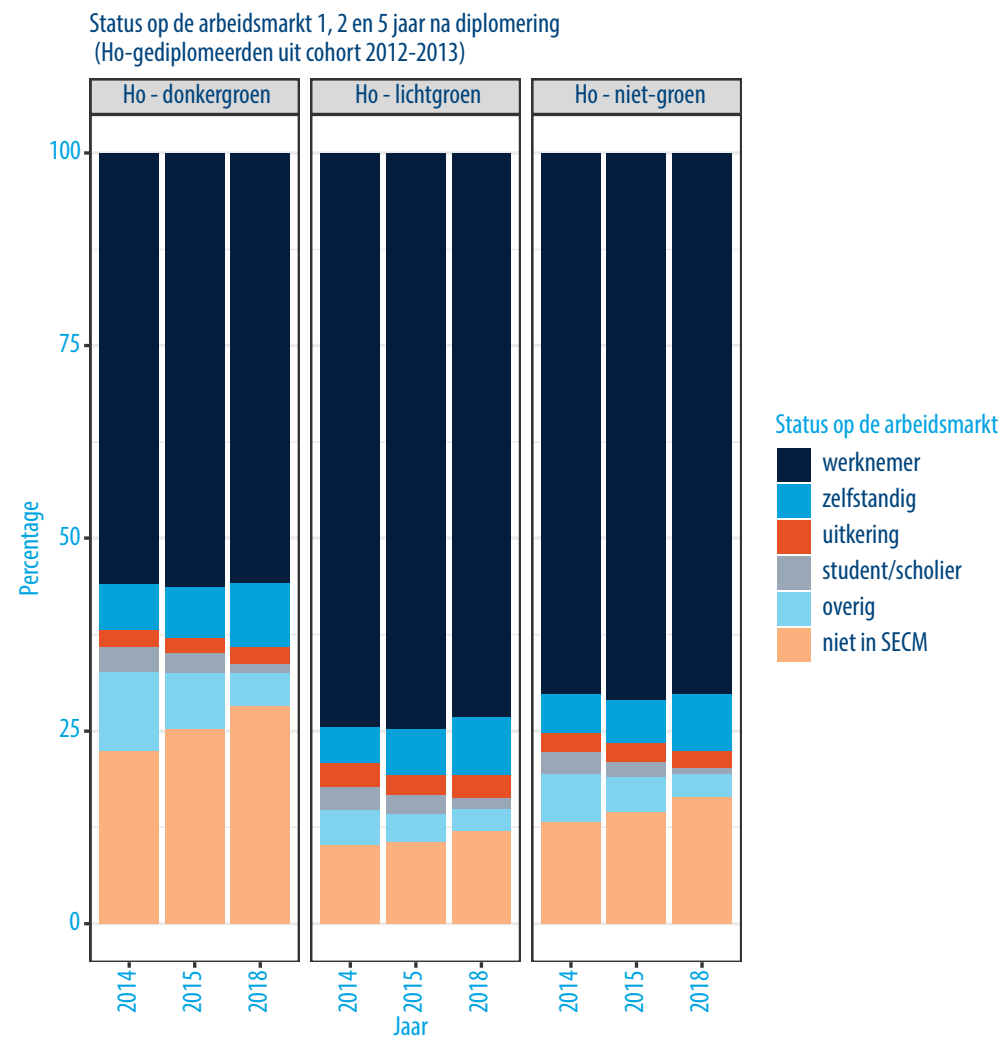

Bron: CBS microdata, bewerking ROA 


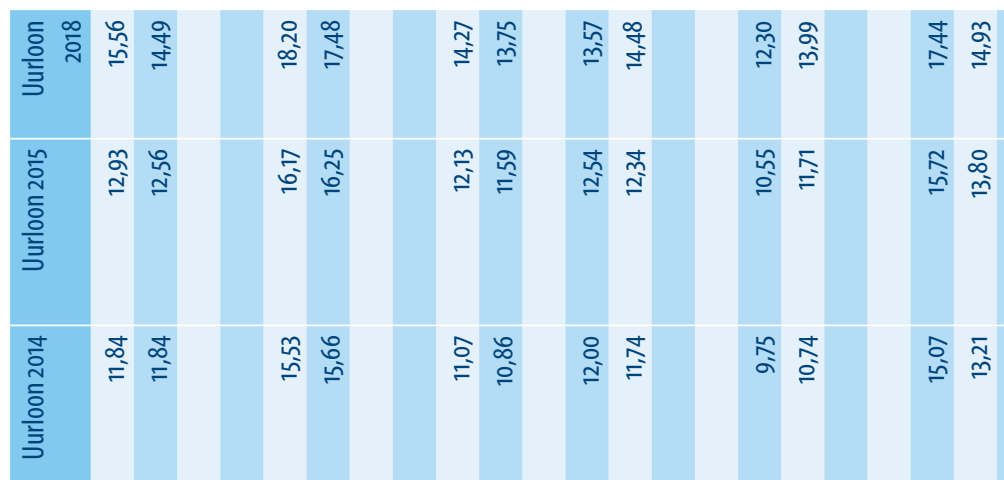

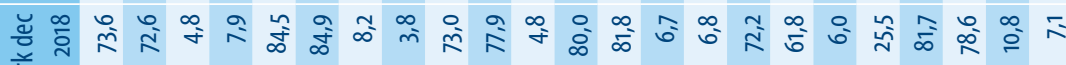
竞

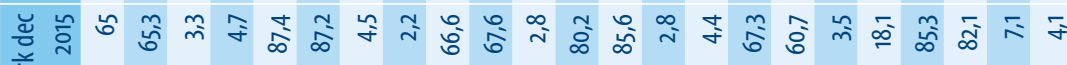
产

(a)

䒿

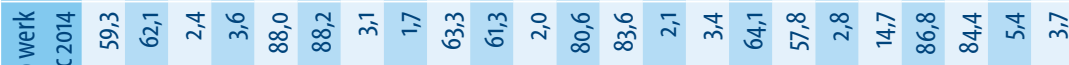
응 융 产

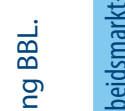

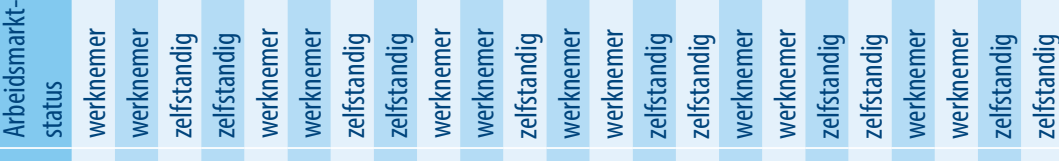

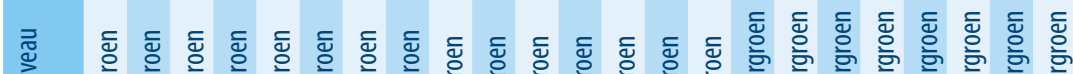

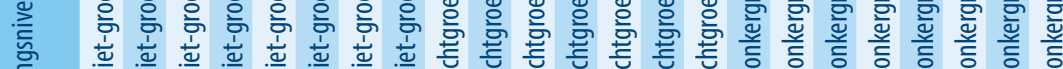

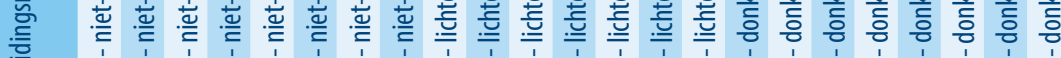

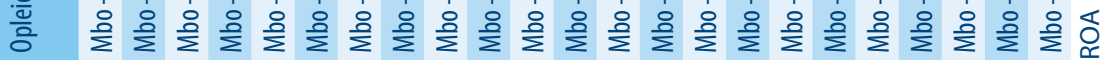

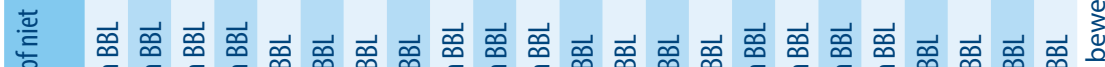
œ 